\title{
Thin Capitalization Rules and Multinational Firm Capital Structure
}


Thin Capitalization Rules and Multinational Firm Capital Structure

Jennifer Blouin, Harry Huizinga, Luc Laeven, and Gaëtan Nicodème 


\title{
IMF Working Paper
}

Research Department

\section{Thin Capitalization Rules and Multinational Firm Capital Structure ${ }^{1}$ Prepared by Jennifer Blouin, Harry Huizinga, Luc Laeven, and Gaëtan Nicodème}

\author{
Authorized for distribution by Stijn Claessens
}

January 2014

\section{This Working Paper should not be reported as representing the views of the IMF.}

The views expressed in this Working Paper are those of the author(s) and do not necessarily represent those of the IMF or IMF policy. Working Papers describe research in progress by the author(s) and are published to elicit comments and to further debate.

\begin{abstract}
This paper examines the impact of thin capitalization rules that limit the tax deductibility of interest on the capital structure of the foreign affiliates of US multinationals. We construct a new data set on thin capitalization rules in 54 countries for the period 1982-2004. Using confidential data on the internal and total leverage of foreign affiliates of US multinationals, we find that thin capitalization rules significantly affect multinational firm capital structure. Specifically, restrictions on an affiliate's debt-to-assets ratio reduce this ratio on average by $1.9 \%$, while restrictions on an affiliate's borrowing from the parent-toequity ratio reduce this ratio by $6.3 \%$. Also, restrictions on borrowing from the parent reduce the affiliate's debt-to-assets ratio by $0.8 \%$, which shows that rules targeting internal leverage have an indirect effect on the overall indebtedness of affiliate firms. The impact of capitalization rules on affiliate leverage is higher if their application is automatic rather than discretionary. Furthermore, thin capitalization regimes have aggregate firm effects: they reduce the firm's aggregate interest expense but lower firm valuation. Overall, our results show than thin capitalization rules, which thus far have been understudied, have a substantial effect on the capital structure within multinational firms, with implications for the firm's market valuation.
\end{abstract}

JEL Classification Numbers: G32, H25.

Keywords: Thin capitalization rule; Multinational firm; Capital structure; Taxation. Author's E-Mail Addresses: blouin@,wharton.upenn.edu; H.P.Huizinga@uvt.nl; 1laeven@imf.org; Gaetan.Nicodeme@ec.europa.eu

\footnotetext{
${ }^{1}$ Jennifer Blouin is Associate Professor of Accounting at Wharton, University of Pennsylvania. Contact information: blouin@wharton.upenn.edu, Phone: (215) 898 1266; Harry Huizinga is Professor of Economics at Tilburg University and Research Fellow at the CEPR; Luc Laeven is Lead Economist at the International Monetary Fund, Professor of Finance at Tilburg University, and Research Fellow at the CEPR; and Gaëtan Nicodème is Head of Unit at the European Commission's General Directorate for Taxation and Customs Union and Adjunct Professor in Economics at ULB. The statistical analysis of firm-level data on U.S. multinational companies was conducted by Jennifer Blouin at the Bureau of Economic Analysis, Department of Commerce under arrangements that maintain legal confidentiality requirements. The views expressed in this study are those of the authors and do not reflect those of the US Department of Commerce, the European Commission, the IMF, or IMF Board. We appreciate the helpful comments of Fritz Foley, Niels Johannesen, Richard Sansing, Dirk Schindler, Terry Shevlin, and seminar participants at the University of Chicago, Stanford University, Erasmus University in Rotterdam, the Solvay Brussels School of Economics and Management, Free University of Brussels, the Norwegian School of Economics (NHH Bergen), the University of North Carolina's Global Issues in Accounting Conference, the 2013 ZEW/CBT Conference in Mannheim, the 2013 CESifo Public Sector Conference, and Oxford University's tax symposium.
} 


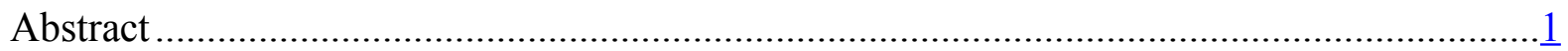

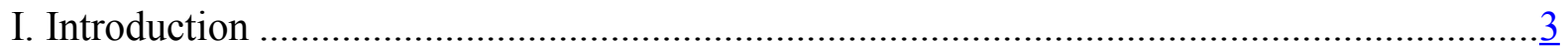

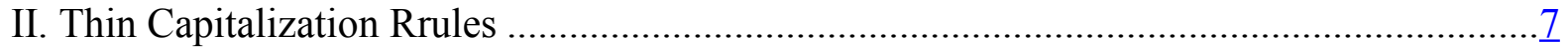

III. Multinational Firm and Country Data....................................................................

IV. Empirical Results ....................................................................................

A. The impact of introductions of thin capitalization regimes …..........................12

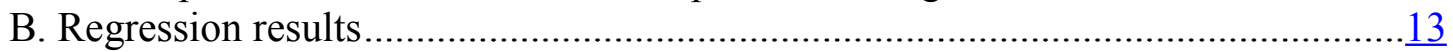

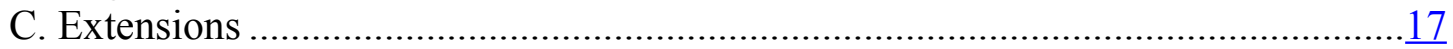

D. Aggregate firm implications of thin capitalization rules .................................. 18

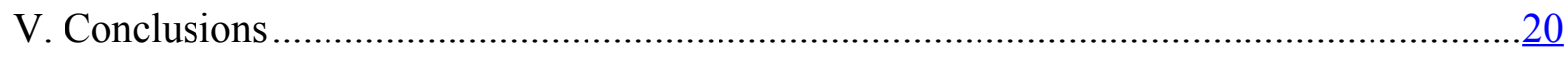

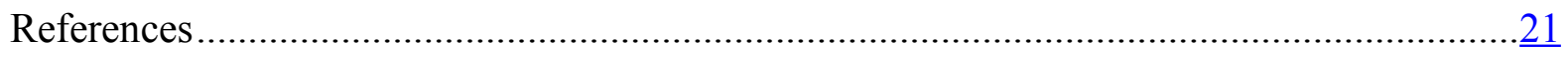

Table

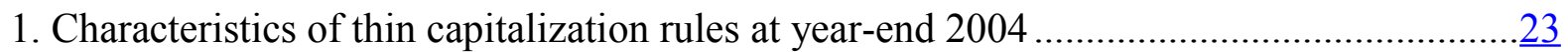

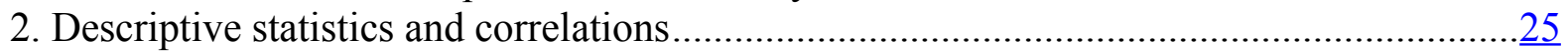

3. The introductive of thin capitalization rules and borrowing ....................................... $\frac{28}{29}$

4. Thin capitalization restrictions on total debt and total borrowing by US affiliates .............29

5. Thin capitalization restrictions on internal debt and borrowing

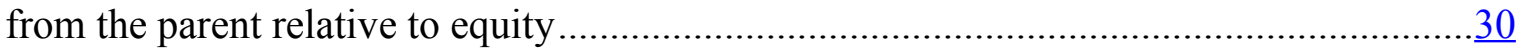

6. Thin capitalization restrictions on the share of internal debt

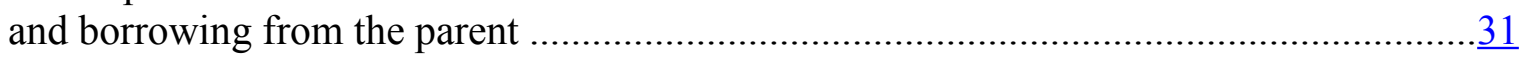

7. Internal leverage restrictions and the total debt and total borrowing

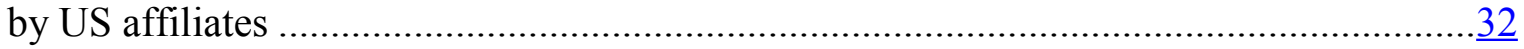

8. The application of thin capitalization rules and US affiliate financing ...........................33

9. The short-term impact of changes in thin capitalization rules on

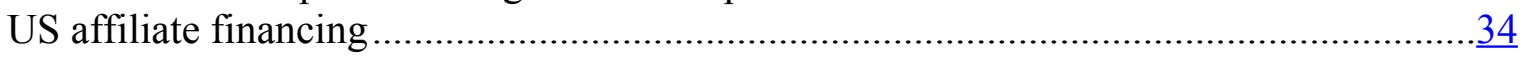

10. Impact of thin capitalization rules on Tobin's Q, debt, and interest expense at the

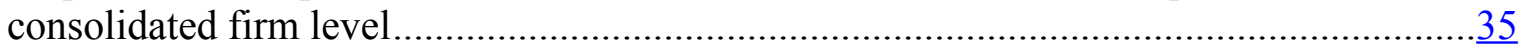

Figure

1. US affiliates' debt ratios and corporate taxation..................................................... 


\section{INTRODUCTION}

Interest on debt is generally deductible from taxable income at the corporate level. This provides firms with an incentive to finance their operations with debt rather than equity, especially in high tax countries (Graham, 1996, 2000; MacKie-Mason, 1990). To counteract the negative consequences of debt finance for tax collection, many countries have instituted thin capitalization rules that restrict the deductibility of interest above a certain debt level. In principle, multinational enterprises can adjust the leverage of their foreign subsidiaries easily through international debt shifting (Desai, Foley, and Hines, 2004; Huizinga, Laeven, Nicodème, 2008). This suggests that quantitative restrictions on foreign affiliates in the form of thin capitalization rules can be an important determinant of foreign affiliate leverage. However, studies of capital structure in the corporate finance literature typically capture tax advantages of debt exclusively using information on tax rates, without consideration of other differences in tax codes that constrain leverage and thus the value of tax shields (see, for example, Rajan and Zingales, 1995). This is surprising given the prevalence of these measures and their potential influence on capital structure decisions. Thin capitalization rules thus are an important source of understudied variation in tax rates in capital structure studies.

This paper examines how thin capitalization rules worldwide affect the capital structure of foreign affiliates of US multinational firms. Countries' thin capitalization regimes differ among several key dimensions. First, they tend to vary in the definition of the maximum debt ratio, beyond which interest on debt is no longer deductible. The definitions of the maximum debt ratios fall into two main categories: either they restrict total debt (relative to assets or alternatively equity), or they limit debt from related parties (relative to equity). Second, thin capitalization rules differ in the treatment of interest on debt determined to be excessive. For instance, interest deductibility may be denied only for interest on debt in excess of the limit or on all debt, and also possibly be requalified as a dividend with unfavorable tax consequences. Third, countries vary in the zeal of their enforcement of thin capitalization rules. In some countries, the rules trigger an automatic disallowance of interest deductions so there is not subjectivity in the thin capitalization thresholds. Yet, other countries apply some discretion in their application, and consider the corporate indebtedness at similar, but unrelated, firms (i.e., firms that stand at "arm's length") to determine whether interest deductibility is limited.

The effect of thin capitalization rules on multinational firm leverage is not a priori

evident. Despite clear evidence from managerial survey results reported in Graham and Harvey (2001) that tax implications are important determinants of firm leverage, the empirical literature on taxation and capital structure, as reviewed in Auerbach (2002) and Graham (2003), has found it remarkably difficult to identify strong effects of tax incentives on capital structure, due in part to measurement problems and lack of variation in tax rates. This suggests we should expect to find it similarly challenging to establish strong effects of thin capitalization rules on affiliate leverage. Moreover, thin capitalization rules can be very detailed and we therefore need to capitalize on the heterogeneity in these rules to identify clear effects. As Desai, Foley, and Hines (2004) point out: "These rules are typically vaguely worded and seldom, though arbitrarily, 
imposed, making their effects difficult to analyze quantitatively; any impact they have is likely to reduce the estimated significance of factors influencing total indebtedness." Also, their effectiveness will depend on the extent to which they are enforced by local tax authorities. Finally, even if we find that thin capitalization rules constrain affiliate leverage, as one would expect, it is not a priori clear what their impact is on overall firm leverage and valuation because multinational firms can relocate debt and activity away from countries with strict thin capitalization rules.

We address these concerns by using both broad measures of thin capitalization rules that simply denote whether such rules are in place, in addition to specific, well-defined aspects of thin capitalization rules, to thus strike a balance between power and precision in identifying the sensitivity of affiliate leverage to thin capitalization rules. Moreover, we achieve identification by exploiting the substantial cross-country and time variation in thin capitalization rules, and by considering the differential impact of these rules across affiliates within the same multinational firm, thus contributing to the broader literature on taxation and debt, where the lack of variation in corporate income tax rates has made it difficult to isolate taxation effects. In addition, we study the aggregate implications of thin capitalization rules by investigating their impact on the firm's overall leverage, interest expense bill, and market valuation.

For our empirical analysis, we have constructed a unique data set on each of these dimensions of thin capitalization regimes for 54 countries over the years 1982-2004. The end of the sample period is determined by the last year for which we have detailed debt information on foreign affiliates. ${ }^{2}$ There is much variation across countries both in terms of the existence of thin capitalization rules and whether such rules apply to total or internal leverage. For 2004, we find that 27 of these 54 countries had enacted explicit thin capitalization regimes. This group can be divided into 16 countries that restricted total leverage (i.e., the ratio of total debt to assets), while 11 countries restricted internal leverage (i.e., the ratio of debt from related parties to equity). Furthermore, 17 countries apply their thin capitalization rules automatically, while 10 countries apply discretion based on comparisons with corporate indebtedness in arm's length situations.

Our empirical analysis relates information on the existence and stringency of thin capitalization regimes to the total or internal leverage of foreign affiliates of US multinationals using confidential data from the US Bureau of Economic Analysis. Given the prevalence of restrictions on total leverage in 2004, we first consider how these restrictions affect the total leverage of foreign affiliates. On average, the existence of a total leverage restriction reduces an affiliate's total leverage by $1.9 \%$. Stricter regimes reduce total leverage more; we find that lower allowable total leverage ratios are associated with lower levels of leverage.

\footnotetext{
${ }^{2}$ Note that the 2009 BEA annual (BE-10 and BE-11) surveys do not include as detailed information on the types of liabilities as prior surveys.
} 
In analogous fashion, we consider the impact of thin capitalization rules that limit internal leverage on US affiliate internal leverage. The existence of such rules on average reduces the internal leverage ratio by $6.3 \%$. In addition, internal leverage declines with the allowable internal leverage ratio. The large average impact of restrictions on internal debt may reflect that multinationals can easily adjust internal leverage on the basis of tax considerations.

A high responsiveness of internal debt to restrictions on internal leverage suggests that such restrictions can have a material impact on an affiliate's total leverage as well. Indeed, we find that the existence of restrictions on internal leverage on average reduces total leverage by $0.8 \%$. Restrictions on internal leverage thus materially affect the foreign affiliate's overall leverage, going beyond affecting whether the parent firm funds its foreign affiliate through debt or equity.

The impact of thin capitalization rules on leverage ratios depends importantly on how they are applied. The impact of the existence of thin capitalization rules generally on total leverage, in particular, is about twice as large if their application is objective (i.e., automatic rather discretionary). In addition, an impact on total leverage of internal leverage restrictions specifically is only found if its application is automatic.

As an extension, we exploit variation over time in thin capitalization rules to examine how new thin capitalization regimes affect the various leverage ratios in the first years following their introduction by estimating regressions of our leverage ratios in first differences between benchmark years. The short-term response of thin capitalization rules generally tends to be smaller than the average or long-term response. However, total leverage (internal leverage) responds quickly and fully to the introduction of a total (internal) leverage restriction.

Furthermore, we show that thin capitalization regimes have aggregate firm effects. They reduce the multinational firm's aggregate interest expense bill and lower the overall valuation of the firm, consistent with a reduced worldwide deductibility of interest from taxable income. Taken together, our results suggest that thin capitalization rules are an effective policy instrument to constrain leverage within the prescribed limits, with implications for firm valuation as a whole.

Previously, Desai, Foley and Hines (2004) have examined the impact of taxation on the capital structure of US multinationals using the same data source from the US Bureau of Economic Analysis. Using data over the 1982-1994, they find that a 10\% increase in the hostcountry tax rate raises the total debt to assets ratio of US foreign affiliates by $2.6 \%$ (in their regression 1 of Table II). We extend their analysis by considering the joint impact of hostcountry taxation and thin capitalization rules on affiliate leverage through 2004. In a regression analogous to Desai, Foley and Hines (2004), we find that a 10\% higher local tax increases the total debt to assets ratio by $2.0 \%$, consistent with their findings for an earlier period.

Other work on the impact of taxation on the capital structure of multinational firms similarly tends to ignore thin capitalization rules. Similar to Desai, Hines and Foley (2004), 
Huizinga, Laeven, and Nicodème (2008) report that a $10 \%$ increase in the local tax rate is associated with a rise in the ratio of a foreign affiliate's total debt to assets ratio of about $2 \%$ using data from 32 European countries between 1994 and 2003. Similar results are also obtained by Mintz and Weichenrieder (2005) using data on the foreign subsidiaries of German multinational firms. Using data on affiliates of US multinationals, as we do, Hines and Rice (1994) show that US firms typically can arrange their finances to benefit from the deductibility of interest expense in high-tax countries by deferring US taxes until profits are repatriated from foreign affiliates. Froot and Hines (1995) examine the effects of limits to the deductibility of interest expenses due to the US allocation rules on the financing of US multinational firms; Desai and Hines (1999) analyze changes in joint venture capital structure in response to foreign tax credit limitations; Altshuler and Grubert (2003) study inter-affiliate transactions motivated by tax rules among affiliates of US multinationals; and Newberry and Dhaliwal (2001) examine the role of local tax-loss carry-forwards on the international location of debt issuance by US multinationals.

To the best of our knowledge, ours is the first paper to consider the role of thin capitalization rules in the context of US multinational firms. Empirical analysis on the economic effects of thin capitalization rules has so far been limited to German firms, using the Bundesbank's MiDi database, which provides data on German multinationals and their foreign affiliates. A first set of papers investigate the impact of a change to Germany's thin cap rule in 2001, which reduced the limit on the internal debt to equity ratio from 3 to 1.5 , on affiliate leverage. Wamser (2008) finds that firms for which the rule was binding prior to the 2001 reform increased their external debt to capital ratio by $2.5 \%$ compared to those for which the rule was not binding. Weichenrieder and Windischbauer (2008) find a similar result and point to a loophole in the legislation which offers a more lenient thin cap rule for holding companies.

A second set of papers look more generally at the effectiveness of thin capitalization rules in the host countries of foreign affiliates of German multinationals. Overesch and Wamser (2010) find a negative effect of thin capitalization rules on internal debt based on German inbound investment data from 1996 to 2004. Finally, Buettner, Overesch, Schreiber and Wamser (2012) take into account information on thin capitalization rules to investigate the tax sensitivity of the capital structure of the foreign subsidiaries of German multinationals. ${ }^{3}$ In particular, they use data on the existence and maximum debt ratio of thin capitalization regimes in 29 countries over the 1996-2004 period. They report that the existence of a thin capitalization rule reduces the impact of a $10 \%$ tax increase on the ratio of total debt to assets for German foreign subsidiaries from $2.1 \%$ to $1.6 \%$. Their regression analysis, however, does not directly control for the existence of thin capitalization rules, and thus potentially confounds the direct impact of thin

\footnotetext{
${ }^{3}$ At a theoretical level, Haufler and Runkel (2012) show that tax competition between two identical countries leads to inefficiently low tax rates and inefficiently lax thin capitalization rules (and inefficiently high tax-deductible internal debt of multinational firms), hence a coordinated tightening of thin capitalization rules benefits both countries, even though it intensifies competition via tax rates.
} 
capitalization rules per se with their indirect effect through a changed tax sensitivity of leverage. In our estimation, we explicitly include information on thin capitalization rules where indicated. In addition, we collect information on thin capitalization rules for a much broader set of 54 countries, which allows us to distinguish the effects of the existence of thin capitalization rules targeting total versus internal leverage on foreign-affiliate capital structure. Furthermore, our data set on thin capitalization rules is more detailed, which allows us to estimate how various features of thin capitalization regimes, including the method of applying thin capitalization rules, affect their impact on foreign-affiliate capital structure. And, unlike existing work, we consider the aggregate implications for leverage and valuation for the firm as a whole.

The paper continues as follows. Section 2 presents our international data set on thin capitalization rules. Section 3 discusses the firm-level and other country-level data used in this study. Section 4 presents the empirical results. Section 5 concludes.

\section{Thin Capitalization RUles}

This section describes our international data set on thin capitalization regimes. We have collected information on the existence and main features of thin capitalization regimes in 54 countries over the 1980-2004 period. This information has been gathered from a variety of sources, including the International Bureau for Fiscal Documentation, Brosens (2004), and national tax authorities. Our focus is on regimes applicable to firms that are affiliates of foreign parents.

In practice, thin capitalization regimes differ widely across countries in the restrictions they put on the tax deductibility of interest on company debt, in the discretion that authorities have in applying these restrictions, and in the alternative tax treatment of company interest that is applicable in case full interest deductibility is denied.

Table 1 provides information on thin capitalization rules internationally in 2004 . As seen in column 1, 27 out of 54 countries in the sample had an explicit thin capitalization regime in that year. ${ }^{4}$ The year of first introduction of an explicit thin capitalization regime is indicated in column 2. Early adopters included Canada in 1972 and France in 1979, followed by Australia, Indonesia, the United Kingdom, and the United States in the 1980s. Other countries enacted their thin capitalization rules after 1990. For completeness, the table also denotes the year of adoption for those countries that introduced thin capitalization rules after 2004, the end of our sample period.

Thin capitalization regimes cap the amount of debt for which interest is tax deductible. Typically, interest deductibility is restricted if a measure of the company's debt relative to its

\footnotetext{
${ }^{4}$ Several other countries implicitly limited interested deductibility of foreign subsidiaries by having general antiabuse provisions against excessive deductions of interest from taxable income.
} 
assets or equity exceeds a certain ratio. The exact definitions of the debt measure in the numerator of the ratio and of assets or equity in its denominator vary widely across countries. As seen in column 3, the pertinent debt measure can be total debt, internal debt from a single related party, total internal debt, total internal foreign debt, or total foreign debt. The thin capitalization ratio considers the relevant debt measure relative to total assets (only for the case of New Zealand), total equity, internal equity from a single related party, total internal equity, total internal foreign equity, or total foreign equity, as seen in column 4 . The main distinction among the various possible definitions of the thin capitalization ratio is whether it restricts interest deductibility for total debt or internal debt. In the table, 16 countries are seen to limit interest deductibility for total debt, while 11 countries limit the deductibility for internal debt. The numerical value of the thin capitalization ratio is presented in column 5. Argentina, for instance, imposes a ratio of total debt to total equity of 2 .

Some countries restrict the applicability of the thin capitalization regime to foreign subsidiaries that are substantially owned by their foreign parent. Column 6 lists the minimum ownership share of the foreign parent for the thin capitalization regime to apply. In the case of Denmark, for instance, the thin capitalization regime only applies if the foreign parent has a substantial ownership share of $50 \%$ or more. The minimum substantial ownership share for the thin capitalization rule to apply can be based on direct and/or indirect ownership of the foreign affiliate. As seen in column 7, 17 countries are seen to also include indirect ownership.

Countries differ importantly in how strictly they apply the thin capitalization ratio in determining the interest deductibility for resident foreign subsidiaries. Application of the thin capitalization ratio can be automatic which means that interest deductibility is always restricted if the foreign subsidiary's debt ratio exceeds the relevant ratio (and never restricted if the debt ratio is less than the relevant ratio, the so-called "safe harbor"). Alternatively, a country can use discretion in applying the thin capitalization ratio, considering a foreign subsidiary's leverage in comparison to the leverage of similar resident firms that are not foreign subsidiaries (i.e., comparing actual leverage to leverage on an arm's length basis). Column 8 shows that 17 countries apply their thin capitalization rule automatically.

Next, countries apply one of two primary methods to limit interest deductibility if leverage is found to exceed the pertinent ratio. First, they can simply deny some or all interest deductibility. Second, they can reclassify the excess interest as dividends. The second method of interest limitation implies that nonresident dividend withholding taxes apply, rather than nonresident interest withholding taxes. Hence, reclassification of interest as dividends is the harsher remedy, if the pertinent dividend withholding tax exceeds the alternative interest withholding tax. In column 9, we see that 18 countries only restrict interest deductibility, while 9 countries in addition reclassify interest as dividends.

The disallowance of interest can apply to interest on all debt, as is the case in Latvia, or only to interest on debt in excess of the ratio limit, as is the case in all other countries (see column 10). At the same time, the affected interest payments can be interest payments to the 
provider of credit on a net basis, as in the case of the Netherlands, or alternatively on a gross basis, as in all other cases (see column 11). Finally, the thin capitalization rule can apply to debt from all sources (including domestic sources), to debt only from foreign sources, or to debt from foreign, non-EU sources, as in the case of Spain (see column 12).

In the empirical work, we include variables reflecting the existence, stringency, and automatic application of thin capitalization rules based on information as reflected in Table 1.

\section{Multinational Firm And Country Data}

Our empirical work uses data on the financial statements of US multinationals and their foreign affiliates as collected by the Bureau of Economic Analysis in its annual survey of US Direct Investment Abroad. Such reporting is made on a confidential and compulsory basis, which enhances the representativeness of the data. Our sample contains data for five benchmark years (1982, 1989, 1994, 1999 and 2004) and 54,273 affiliate-year observations.

The empirical analysis considers the impact of thin capitalization regimes on two affiliate-firm leverage variables. First, Total leverage is the ratio of total US foreign affiliate debt to assets. This total leverage variable is directly affected by thin capitalization regimes that restrict total debt. Second, Internal leverage is the ratio of internal debt owed to the US parent to equity, and is directly affected by thin capitalization regimes that target internal debt. ${ }^{5}$ To gauge the broader implications of restrictions on internal debt for affiliate leverage, we in addition examine the Internal debt share, defined as the ratio of internal debt relative to total debt. From Panel A of Table 2, we see that Total leverage, Internal leverage and Internal debt share have mean values of $0.552,0.154$, and 0.084 in the overall sample, respectively. However, there is much variation in these leverage ratios across firms. For example, while Internal debt share is close to zero for the median affiliate firm in the sample, the standard deviation of Internal debt share is substantial at 0.352. Additionally, as seen in Figure 1, all three debt variables have trended down over the 1982-2004 period. The average of Total leverage in particular has declined from $59.4 \%$ in 1982 to $51.0 \%$ in 2004, while Internal leverage declined from $12.0 \%$ in 1982 to $2.5 \%$ in 2004 . Over the same period, Internal debt share declined from $14.9 \%$ to $6.0 \%$, indicating a reduced reliance on internal finance by US multinationals.

The empirical analysis relates the affiliate debt variables to tax policy variables, as well as a host of affiliate-level and host-country control variables. To allow comparison with earlier

\footnotetext{
${ }^{5}$ The BEA data provide three categories of liabilities: (a) trade accounts and trade notes payable (current); (b) other current liabilities and long-term debt and (c) o ther noncurrent liabilities. Our total leverage variables are based on category (b). Because the BEA combines categories (a) and (b) for reporting internal liabilities, our internal leverage includes trade credit. As a limitation, the BEA data do not provide any information on intercompany debt with other affiliates in the organization. The only information provided is the liability to the US parent. So, there may be affiliates that appear to have low intercompany debt while in reality holding debt from other affiliates within the group.
} 
results in the literature, our choice of control variables is determined by those used in previous studies on international capital structures, in particular those by Rajan and Zingales (1995) and Desai, Foley, and Hines (2004). Our measure of tax incentives is Country tax rate, constructed as the median corporate tax rate in the affiliate host country estimated annually using affiliate-level effective tax rates. ${ }^{6}$ A higher corporate tax burden is expected to increase affiliate leverage. The decline in Country tax rate in Figure 1, along with the declines in Total leverage and Internal leverage, is consistent with this. The concomitant decline in Internal debt share suggests a relatively large sensitivity of internal debt to host-country taxation.

We define several variables to represent the existence, stringency, and method of application of thin capitalization regimes. To start, Thin cap restriction is a dummy variable that equals 1 if a country has an explicit thin capitalization, and zero otherwise. From Panel A of Table 2, we see that a thin capitalization regime applies in $58.1 \%$ of our affiliate-year observations. Next, we distinguish whether the regime restricts the use of total debt or the use of internal debt. Specifically, Total leverage restriction is a dummy variable that equals 1 if a country imposes a restriction related to total debt (relative to assets or equity), and zero otherwise, while Internal leverage restriction is a dummy variable that equals 1 if a country imposes a restriction on the use of internal debt (relative to equity). Mean values for these variables in Table 2 imply that the thin capitalization restriction applies to total debt in $25.2 \%$ of our observations (or $43.4 \%$ of the affiliates facing thin capitalization interest limitations).

As a measure of thin capitalization regime stringency, Total leverage ratio is the maximum value of the ratio of total debt to assets. The Total leverage ratio is constructed as $\frac{\phi}{1+\phi}$ where $\phi$ is the maximum total debt-to-equity ratio, in case the ratio test applies to the total debt to equity ratio. Total leverage ratio has a value of one if no total leverage restriction applies. The sample mean for this variable is 0.904 . Analogously, Internal leverage ratio is the maximum value of the ratio of internal debt to the sum of internal debt and equity. Internal leverage ratio is constructed as $\frac{\theta}{1+\theta}$ where $\theta$ is the maximum internal debt to equity ratio, in case an internal leverage restriction applies. Internal leverage ratio has a value of one if no internal leverage restriction applies. The mean value for this variable is 0.895 . To capture discretion in the application of the thin capitalization regime, Arm's length is a dummy variable that equals 1 if the application of the thin capitalization rules is based on subjective criteria such as comparisons to peers, and zero otherwise. Arm's length is one in $40.6 \%$ of the instances where a thin capitalization regime is in force.

\footnotetext{
${ }^{6}$ We follow Desai, Foley and Hines (2001) and estimate the country level tax rate as the median of affiliates' ratio of tax expense to pre-tax income. We eliminate affiliate observations with negative net income in our country-level tax rate estimates.
} 
Next, there are four non-tax, affiliate-level control variables constructed using BEA data. First, Net PPE/assets is the ratio of net property, plant and equipment to total assets in the affiliate. Tangible assets can be depreciated and provide a non-debt tax shield to minimize taxable profit (DeAngelo and Masulis, 1980). At the same time, tangible assets may serve as collateral enhancing leverage (Rajan and Zingales, 1995). Second, EBITDA/assets is the ratio of earnings before interest, depreciation and amortization to total assets. Profitable firms may have easier access to credit, providing a positive relation between EBITDA/assets and leverage. Conversely, profitable firms have the means to pay down their debts reducing their leverage (as suggested by the pecking order theory of Myers and Majluf (1984)). Third, Log of sales is the logarithm of sales as a proxy for affiliate size. ${ }^{7}$ Larger firms may have easier access to credit thanks to higher asset diversification and lower bankruptcy risks giving rise to higher leverage. Fourth, Growth options is the compounded annual growth rate of total affiliate sales at the industry and country level. This variable captures the prospects of future profitability and the implied borrowing capacity. Hence, this variable is expected to be positively related to leverage.

We use three host-country level variables as additional controls. First, Creditor rights is an index of creditor rights from Djankov, McLiesh and Shleifer (2007). Better creditor rights are generally expected to facilitate leverage. Better creditor rights, however, by deepening external debt markets may reduce the need for internal finance, and hence could be negatively related to internal leverage. Second, Political risk is the annual index of political risk from the International Country Risk Guide, rescaled so that a higher score indicates a higher risk. Its impact on leverage is a priori ambiguous. Higher political risks may lead creditors to reduce their lending to companies in the host country. On the other hand, from a company's perspective, a higher political risk may encourage borrowing to reduce the value at risk in the host country. Third, Rate of inflation is the annual percentage change in the consumer price index from the World Development Indicators database of the World Bank. Inflation is potentially negatively related to leverage if it increases the risk premium to be paid to obtain credit. On the other hand, higher inflation rates generally engender higher nominal interest rates increasing the value of the debt tax shield, which could increase leverage.

Panel B of Table 2 reports regression variables at the aggregate firm level (the next section provides more details on the construction of these variables). Aggregate thin cap restriction is the ratio of the sum of the assets of foreign affiliates subject to a thin capitalization restriction relative to the total assets of the consolidated firm. Aggregate total leverage restriction is the ratio of the sum of the assets of foreign affiliates subject to a total leverage restriction relative to the total assets of the consolidated firm. Aggregate internal leverage restriction is the ratio of the sum of the assets of foreign affiliates subject to an internal leverage restriction relative to the total assets of the consolidated firm. Aggregate interest expense is the ratio of total interest expense to total assets of the consolidated worldwide firm. Aggregate

\footnotetext{
${ }^{7}$ Sales is preferred to assets because this latter appears in the denominator of our dependent variables. In addition, using assets would create a bias towards asset-intensive industries.
} 
interest expense to debt is the ratio of total interest expense to total debt of the consolidated worldwide firm.

The data indicate that thin capitalization rules are relevant from the perspective of the multinational firm as a whole, with on average about 15 percent of the multinational firm's assets being subject to a thin capitalization restriction. Among these assets, on average about 6 percent of assets are subject to a total leverage restriction and about 9 percent of assets are subject to an internal leverage restriction. Interest expense on debt averages about 11 percent, reflecting that borrowing costs are denominated in nominal terms and subject to sovereign risk in the host country of the affiliate firm.

Panel $\mathrm{C}$ of Table 2 provides correlations among main debt, tax policy, and control variables. Total leverage is seen to be positively correlated with the Country tax rate, and negatively correlated with Thin cap restriction, Total leverage restriction and Internal leverage restriction. Among the host-country control variables, Total leverage is positively correlated with Creditor rights and negatively correlated with Political risk. Furthermore, Country tax rate and Thin cap restriction are positively correlated, indicating that high-tax host countries are more likely to have thin capitalization regimes. Consistent with this, Country tax rate is positively related to Internal leverage restriction, but contrary to this it is negatively correlated with Total leverage restriction.

\section{EMPIRICAl Results}

This section presents empirical results on the impact of thin capitalization regimes on the capital structure of the foreign affiliates of US multinationals. In subsection 4.1, we present the results of univariate tests of the effects of the introduction of thin capitalization regimes on total and internal leverage. Subsection 4.2 presents the results of regressions that relate these two variables and also the internal debt share to the existence of thin capitalization regimes and the implied limits on debt ratios. Subsection 4.3 presents several extensions. First, we examine whether thin capitalization regimes affect the main debt ratios differently depending on whether the rules are applied automatically or take into account arm's length considerations. Second, we exploit cross-country variation over time in the introduction of thin capitalization regimes to examine how new thin capitalization regimes affect the various debt ratios in the short-term, defined as the first year after their introduction. Finally, in subsection 4.4 we construct measures of the extent to which US multinationals are subject to thin capitalization regimes worldwide at the consolidated firm level to see whether global thin capitalization regimes affect valuation, total leverage, and interest payments at the level of the overall multinational firm.

\section{A. The impact of introductions of thin capitalization regimes}

In this subsection, we report univariate tests of the impact of introductions of thin capitalization rules on mean values of affiliate total and internal leverage. Focusing on these 
regime changes enhances the identification of the impact of thin capitalization rules on affiliate debt because it is unlikely that the introduction of thin capitalization rules in non-US countries is endogenously determined by US affiliate capital structures. During the sample period, eight countries have introduced a total leverage restriction where we have sufficient data to construct ex ante and ex post mean leverage values. Panel A of Table 3 lists the country names, the ex ante and ex post mean values of Total leverage and Internal leverage, and the significance levels of tests regarding whether ex post and ex ante mean values of the total and internal leverage variables are different. For all eight introductions, the ex post mean value of Total leverage is seen to be lower than the ex ante mean value. Across these cases, the introduction of a total leverage restriction reduces mean Total leverage on average by $4.5 \%$. The reduction in total leverage is statistically significant in three-quarters of the countries. Internal leverage, in turn, also declined in all eight cases, and significantly in six cases. The mean decline in Internal leverage is $4.5 \%$.

During the sample period, seven countries introduced an internal leverage restriction where we can compare ex ante and ex post mean leverage variables as seen in Panel B. ${ }^{8}$ In each of these seven cases, the introduction occasioned a drop in the mean Total leverage variable, and the drop in mean Total leverage is statistically significant for all but one introductions. The overall mean drop in Total leverage was $4.6 \%$. In all seven instances, we also observe a reduction in Internal leverage, with six of these reductions being statistically significant. The overall mean drop in Internal leverage is 3.3\%. These results suggest that the introduction of thin capitalization rules tends to have a significant causal effect on affiliate leverage. In what follows, we confirm this using regression analysis when controlling for other contemporaneous factors that could potentially confound these univariate tests. But first we turn to regressions that estimate the average effect of thin capitalization rules on affiliate leverage.

\section{B. Regression results}

In this section, we report regressions that relate measures of US affiliate borrowing to variables describing various aspects of thin capitalization regimes, in addition to traditional correlates of capital structure employed in the literature (see, for example, Rajan and Zingales, 1995; and Desai, Foley, and Hines, 2004). As discussed, there is much variation in thin capitalization rules, with $43 \%$ of thin capitalization regimes in our sample restricting total leverage. We start with considering the determinants of Total leverage, including information on the existence and stringency of thin capitalization regimes that restrict total leverage. Then we consider analogously how thin capitalization regimes, and in particular regimes that restrict internal leverage, affect the Internal leverage variable.

\footnotetext{
${ }^{8}$ Note that Australia has adopted both an internal and external thin capitalization regimes during our sample period. In 1987, Australia adopted an internal leverage restriction and then changed to a total level restriction in 2002.
} 
Next, we consider whether internal leverage restrictions affect the affiliate financing structure beyond the ratio of internal debt to equity. Internal leverage restrictions possibly change the mix of internal and external debt of the firm. To examine this, we first consider the impact of internal leverage restrictions on the Internal debt share. The evidence of Table 3 suggests that internal leverage restrictions affect Total leverage as well. To conclude, therefore, we examine the relationship between internal leverage restrictions and Total leverage as well. Throughout, regressions include parent, industry, and year fixed effects. Standard errors control for potential two-way clustering across observations at the country and industry level.

Table 4 reports regressions of an affiliate's total leverage. Regression 1 relates this variable to Country tax rate and control variables. The estimated coefficient for the country tax rate is 0.197 and it is significant at $1 \%$. Thus, affiliates in high-tax host countries have higher total leverage to benefit more from interest deductibility. Among the control variables, total leverage is positively and significantly related to Net PPE/assets, consistent with the view that tangible assets may serve as collateral for borrowings. EBITDA/assets obtains a negative and significant coefficient, suggesting that profitable firms are able to pay down their debts. Log of sales enters the regression with a positive and significant coefficient, indicating that larger firms may have better access to credit. Creditor rights receives a positive and significant coefficient, as creditor protection may increase the supply of credit to the firm. Political risk negatively and significantly affects total leverage. Total leverage is negatively related to Inflation, as interest rates may incorporate higher risk premiums in highly inflationary environments. Finally, total leverage is positively related to Growth opportunities, but the estimated coefficient is statistically insignificant. Overall, these results confirm the findings in Desai, Foley, and Hines (2004) that were estimated using the same dataset for an earlier period.

Regression 2 includes the Thin cap restriction dummy variable that signals the existence of a thin capitalization regime. This variable obtains a coefficient of -0.0214 that is significant at the $1 \%$ level, indicating that thin capitalization regimes generally reduce affiliate total leverage. The tax variable now obtains a somewhat higher coefficient of 0.223 that is significant at $1 \%$, suggesting that the estimate on the tax variable is biased downward in regression 1 on account of the missing thin capitalization variable. In unreported regressions, we find that this reduction in leverage is driven by a decrease in debt rather than an increase in assets.

A thin capitalization regime reduces or eliminates the incentive to take on more debt so as to reduce taxable income. Hence, thin capitalization regimes potentially reduce the sensitivity of the affiliate's borrowing to a country's corporate income tax rate. To test this, regression 3 includes an interaction term of the Country tax rate and Thin cap restriction variables. In this regression, Thin cap restriction and its interaction with Country tax rate obtain coefficients of 0.272 and 0.0183 , respectively, that are insignificant.

In regression 4, we replace the Thin cap restriction variable by the Total leverage restriction variable starting from regression 2 . The Total leverage restriction variable obtains a coefficient of -0.0186 that is significant at $1 \%$. As expected, thin capitalization regimes that 
target total leverage serve to reduce total leverage. Regression 5 includes an interaction term of Country tax rate with Total leverage restriction. The total leverage restriction variable obtains a coefficient of -0.0445 that is significant at $1 \%$, but the interaction term is statistically insignificant.

A key feature of a thin capitalization regime that restricts total leverage is the quantitative value of the maximum total leverage. In regressions 6 and 7, we replace the Total leverage restriction variable with the Total leverage ratio, found in regressions 3 and 4 . The total leverage ratio in these two regressions obtains coefficients of 0.0307 and 0.119 , respectively, which are significant at $10 \%$ and $5 \%$, respectively. Recall that the definition of the total leverage ratio implies that the more lenient the regime, the higher this ratio, hence we expect positive coefficients. These results therefore indicate that a looser quantitative restriction on total leverage enables the affiliate to maintain higher total leverage. The interaction term of Country tax rate and Total leverage ratio in regression 7 is negative and statistically significant suggesting that tighter thin capitalization limits are less constraining in affiliates facing higher tax rates.

Overall, Table 4 shows that thin capitalization regimes, and in particular the Total leverage restriction and the Total leverage ratio variables, have a material impact on Total leverage.

Thin capitalization regimes that restrict internal leverage are expected to have a direct impact on internal leverage. This is what we consider next. Table 5 presents regressions that relate Internal leverage to thin capitalization regimes, and, in particular, to information on the existence and quantitative value of regimes that restrict internal leverage. Otherwise, the regressions in Table 5 are fully analogous to those in Table 4.

In regression 1, the Country tax rate receives a coefficient of 0.368 that is significant at the $1 \%$ level. In regression 2 , the Thin cap restriction dummy enters with a negative coefficient of -0.0800 that is significant at $1 \%$. Regression 3 adds the interaction of the Country tax rate and the Thin cap restriction dummy variable, yielding an estimated coefficient that is statistically insignificant. Regression 4 includes the Internal leverage restriction variable instead of the Thin cap restriction variable, yielding a coefficient of -0.0629 that is significant at $1 \%$. This variable and its interaction with Country tax rate are both statistically insignificant in regression 5. Regression 6 includes the Internal leverage ratio. This variable is estimated with a positive coefficient of 0.196 that is significant at $1 \%$. This is evidence that a quantitative relaxation of an internal leverage restriction engenders higher internal leverage, as is to be expected. Regression 7 in addition includes an interaction of Country tax rate and Internal leverage ratio, providing statistically insignificant coefficients for both the internal leverage ratio itself and the interacted variable. Overall, Table 5 shows that thin capitalization regimes that restrict internal leverage have a material impact on this leverage variable. 
Next, we consider whether internal leverage restrictions affect the financing structure of the US foreign affiliate more broadly, beyond the internal leverage ratio. In particular, we consider in turn the impact of this type of restriction on the Internal debt share and Total leverage.

Table 6 show regressions of the Internal debt share that apart from the different dependent variable are analogous to Table 5. Regression 1 displays a positive relationship between the Internal debt share and the Country tax rate, with an estimated coefficient for the tax variable of 0.117 that is significant at $1 \%$. This is consistent with the view that internal debt is more tax sensitive than external debt. In regression 2 , Thin cap restriction has a negative coefficient that is significant at $10 \%$ suggesting that internal debt is more sensitive to thin capitalization restrictions. In regression 6 , the coefficient on Internal leverage ratio is positive and significant. This is evidence that internal debt expands relative to total debt if the internal leverage restriction is loosened. The Internal leverage restriction and its interaction with Country tax rate, in turn, are estimated with significant positive and negative coefficients in regression 7, suggesting that the internal debt to total debt ratio increases relatively little in hightax countries as the internal leverage restriction is relaxed.

Next, we consider the indirect impact of thin capitalization regimes that restrict internal leverage on total leverage in Table 7 . While thin capitalization rules that restrict internal leverage have a direct bearing only on internal leverage, they may affect total leverage indirectly if internal and external leverage are imperfect substitutes. This is indeed what we find. Specifically, regressions 1 and 2 in Table 7 include the Internal leverage restriction and are otherwise analogous to regressions 4 and 5 of Table 4 . The Internal leverage restriction enters regression 1 of Table 7 with a coefficient of -0.0082 that is significant at $1 \%$. Comparing regression 4 in Table 4 with regression 1 in Table 7, we see that the impact of an internal leverage restriction on total leverage is about half the impact of a total leverage restriction on the same leverage variable. In regression 2, the estimated coefficients for Internal leverage restriction and its interaction with Country tax rate, however, are both insignificant.

Regressions 3 and 4 of Table 4 are analogous to regressions 6 and 7 of Table 4 . In regression 3, the Internal leverage ratio enters with a positive coefficient that is significant at $5 \%$. In regression 4, Internal leverage ratio and its interaction with Country tax rate obtain coefficients that are both insignificant. Overall, restrictions on internal leverage appear to have a significant impact on total leverage.

Results presented thus far may be influenced by the decision where to locate affiliates. To address concerns that location decisions are driving the results, in unreported regressions we rerun the regressions in Tables 4 to 7 for the sample of parents with affiliates in the same set of countries over the period 1982 to 2004 . The results are qualitatively unaltered. 


\section{Extensions}

We first consider how discretion in the application of thin capitalization rules affects the financing structure of the foreign affiliates of US multinationals. Discretion in the application of the thin capitalization rules is captured by the Arm's length variable which signals that interest limitation is not automatic, but entails some subjectivity on the basis of arm's length considerations. Of all thin capitalization regimes, $40.6 \%$ allow for some discretion based on arm's length considerations. Regression 1 of Table 8 includes the Thin cap restriction variable and its interaction with the Arm's length variable in a total leverage regression similar to regression 2 of Table 4. Thin cap restriction and its interaction with Arm's length obtain coefficients of -0.0276 and 0.0169 , respectively, which are both significant. This suggests that the impact of a thin capitalization rule on total leverage is reduced by $61 \%(=0.0169 / 0.0276)$ if rules are applied based on arm's length considerations. Regression 2 includes Total leverage restriction and its interaction with Arm's length in a total leverage regression, yielding a coefficient of -0.0229 for the Total leverage restriction variable that is significant at $1 \%$ and a coefficient of 0.0109 for its interaction with Arm's length that is insignificant. These point estimates suggest that discretion reduces the impact of total leverage restrictions on total leverage by $48 \%(=0.0109 / 0.0229)$, although the effect is not significant. In regression 3 , Internal leverage restriction and its interaction with Arm's length obtain estimates of -0.0200 and 0.0244 that are significant at $5 \%$ and $10 \%$, respectively, suggesting that discretion fully completely cancels out the effect of internal leverage restrictions on total leverage.

Regression 4 includes Thin cap restriction and its interaction with Arm's length in an Internal leverage regression, while regression 5 includes the Internal leverage restriction and its interaction with Arm's length in such a regression. In both regressions, the interaction terms are statistically insignificant. Finally, regression 6 includes Thin cap restriction and its interaction with Arm's length in an Internal debt share regression, while regression 7 includes the Internal leverage restriction and its interaction with Arm's length in such a regression. None of these thin capitalization variables are statistically significant in these two regressions. Overall, Table 8 provides some evidence that discretion reduces the impact of thin capitalization rules on total leverage, but not on internal leverage or the internal debt share.

Next, we are interested to see whether the introduction of a new thin capitalization regime prompts US multinationals to quickly adapt the capital structure of their foreign affiliates to the new regime, and, in particular, in the first years of implementation. To do this, we estimate a set of financial ratio regressions analogous to those in Table 8 in first differences (without the Arm's length variable). These first difference regressions also mitigate concerns that omitted variables may influence our results. The first differences are differences between benchmark years, which cover periods lasting either five or seven years. The results are reported in Table 9, with $\Delta$ denoting that variables are expressed in first differences between benchmark years. Regression 1 includes $\Delta$ Thin cap restriction in a regression of $\Delta$ Total leverage. Note that $\Delta$ Thin cap restriction equals $1(-1)$ in the first years of implementation (abolishment) of a thin capitalization rule, while it is zero in all other years. $\Delta$ Thin cap restriction receives a coefficient 
of -0.0113 that is significant at $10 \%$, suggesting that the introduction of a thin capitalization restriction reduces the total leverage ratio by $1.13 \%$ in its first years. This estimated coefficient is about half of the estimate of -0.0214 for the Thin cap restriction variable in the corresponding Total leverage regression 2 in Table 4, suggesting that the short-run impact of the introduction of a thin capitalization regime is about half of its average or long-term effect.

The $\Delta$ Total leverage restriction variable receives a coefficient of -0.0248 in the $\Delta$ Total leverage regression 2 of Table 9 that is significant at $5 \%$ and of similar magnitude as the corresponding coefficient of -0.0186 in the level regression 4 of Table 4 . Hence, the majority of the effect of a total leverage restriction on total leverage appears to materialize during the first years following its introduction. In the $\Delta$ Internal leverage regression 4 , the included $\Delta$ Thin cap restriction variable has a coefficient of -0.0452 that is significant at $5 \%$ and about half of the corresponding estimate in the level regression 2 of Table 5. However, the $\Delta$ Internal leverage restriction variable obtains a coefficient of -0.117 in regression 5 that is significant at $5 \%$ and is almost twice as large as the corresponding estimate in the level regression 4 of Table 5. This suggests that internal leverage reacts very quickly to a change in the internal leverage restriction, and may even overreact in the short run. At any rate, the evidence suggests that the multinational firm can adjust the internal leverage of a foreign affiliate relatively quickly, possibly because this does not involve any external creditors. In the $\Delta$ Internal debt share regressions 6 and 7 the $\Delta$ Thin cap restriction and $\Delta$ Internal leverage restriction are estimated with insignificant coefficients, which could reflect that the first-years adjustment in this variable tends to be rather small.

Generally, we report evidence that the financial structure of the foreign affiliates of US multinationals, and in particular total and internal leverage, take considerably longer than a few years to adjust to a change in the thin capitalization regime generally. However, Total (Internal) leverage reacts relatively quickly to the introduction of a Total (Internal) leverage restriction.

\section{Aggregate firm implications of thin capitalization rules}

To conclude, we consider how thin capitalization regimes facing the foreign affiliates of US multinationals affect the valuation, leverage, and interest expenses of the multinational firm as a whole. To start, we consider how thin capitalization regimes affect firm valuation as measured by Tobin's $q$, where this variable is constructed as the ratio of the market value of the overall firm's equity plus debt to total assets using data from the Compustat and CRSP databases. Thin capitalization regimes are expected to affect firm valuation negatively, as they imply a reduced tax advantage of debt finance. In regression 1 of Table 10, Tobin's $q$ is related to the Aggregate thin cap restriction variable that measures the extent to which the multinational's operations worldwide are subject to a thin capitalization regime. Specifically, this aggregate variable is constructed as the ratio of the sum of the assets of foreign affiliates subject a thin cap restriction to the total assets of the consolidated firm. Aggregate thin cap restriction is seen to obtain an insignificant coefficient in regression 1 . In regression 2, the aggregate thin 
capitalization variable is split into analogous separate variables that measure the extent to which the multinational's operations are subject to a total leverage restriction and an internal leverage restriction. Aggregate total leverage restriction obtains a negative and significant coefficient in regression 2, while Aggregate internal leverage restriction is estimated to be insignificant. In regressions 3 and 4, we replace Tobin's $q$ in regressions 2 and 3 by Tobin's $q$ net of the firm's industry mean Tobin's q to account for systemic differences in firm valuation at the industry level, and obtain very similar results. The economic effect of total leverage restrictions on firm valuation is substantial. The coefficient estimates in regression 4 imply that a one standard deviation increase in the aggregate total leverage restriction variable of 0.113 would translate into a decrease in industry-adjusted Tobin's q of 0.051 , which is substantial given its mean of 0.239 and its standard deviation of 1.539 .

In regressions 5 and 6 , the dependent variable is the ratio of debt to assets of the consolidated worldwide firm. The aggregate thin capitalization regime variables are estimated to be insignificant in both regressions. The absence of a significant impact of the aggregate thin capitalization variables on worldwide leverage suggests that the multinational firm engages in debt shifting from countries with thin capitalization regimes towards countries that lack such regimes so as to keep overall leverage constant.

In regressions 7 and 8 , the dependent variable is the ratio of interest expenses to total assets of the consolidated firm. In regression 7, this interest expense ratio is seen to be negatively and significantly related to the aggregate thin capitalization regime variable, while in regression 8 it is negatively and significantly related to the separate aggregate total and internal leverage restriction variables. The reduced worldwide interest expenses on account of thin capitalization regimes may reflect that any international debt shifting that occurs leads to lower borrowings in high-interest countries, and vice versa. Also, the lower interest expenses may reflect that thin capitalization regimes cause the multinational to choose financial structures that overall imply less risk to external creditors, for instance on account of more internal equity funding of foreign affiliates. Finally, in regressions 9 and 10 we repeat the aggregate interest expense regressions in columns 7 and 8 by using the ratio of aggregate interest expenses to total debt (rather than assets) at the consolidated firm level as the dependent variable. We obtain qualitatively similar results when scaling interest expenses by total debt rather than total assets, indicating that results are not driven by differences in aggregate leverage, consistent with the results on aggregate debt in regressions 5 and 6 . The economic effect of thin capitalization restrictions on aggregate interest expenses is significant. The coefficient estimates in regression 9 imply that a one standard deviation increase in the aggregate thin capitalization restriction variable of 0.186 would translate into a decrease in aggregate interest expenses 0.025 , which is substantial given its mean of 0.111 and its standard deviation of 0.199 .

Taken together, these results imply that thin capitalization rules affect the capital structure within multinational firms, with aggregate implications for the interest expense and firm valuation of multinational firms. 


\section{Conclusions}

This paper examines the impact of thin capitalization rules that limit the tax deductibility of interest on the leverage of the foreign affiliates of US multinationals. For this purpose, we construct a new data set on thin capitalization rules in 54 countries for the period 1982-2004. The data set provides information about the existence of explicit thin capitalization rules, their stringency, and their application. Overall, in our sample thin capitalization regimes restrict the ratio of an affiliate's total debt to assets in about $43 \%$ of the cases. In other cases, thin capitalization rules restrict the ratio of an affiliate's indebtedness to related parties relative to its equity.

The presence of restrictions on an affiliate's ratio of overall debt to assets on average reduces this leverage ratio by $1.9 \%$. Restrictions on the ratio of an affiliate's borrowing from the parent company to its equity, in turn, on average reduce the targeted leverage ratio by $6.3 \%$. Furthermore, restrictions on borrowing from the parent on average reduce the overall debt to assets ratio of the affiliate by $0.8 \%$. This shows that restrictions on borrowing from related parties have an important role in affecting the affiliate's overall capital structure, going beyond merely affected the parent firm's choice between injecting the foreign affiliate with debt finance or equity finance.

Further, we find that the impact of thin capitalization rules on affiliate leverage is higher, if their application is automatic rather than discretionary. ${ }^{9}$ Finally, by exploiting changes in thin capitalization regimes over time, we find that the first-year impact of new capitalization rules generally on affiliate leverage tends to be part of the long-term effect. However, total leverage (internal leverage) responds quickly and fully to the introduction of a total (internal) leverage restriction. Thin capitalization rules on the affiliates of US multinational firms are found to reduce the overall valuation of the firm, consistent with a reduced worldwide deductibility of interest from taxable income.

Overall, our results show than thin capitalization rules, which thus far have been understudied, have a substantial effect on capital structure within multinational firms. They therefore provide an important qualification of existing studies on capital structure and taxation of multinational firms, which thus far has generally ignored the effects of thin capitalization rules. More broadly, our results offer new evidence on the relevance of taxation for corporate debt, by focusing on thin capitalization rules that, more than statutory corporate income tax rates, display great variation across countries.

\footnotetext{
${ }^{9}$ This suggests that the application of thin capitalization rules should be automatic if the purpose is to limit tax base erosion through interest deductions. The $\operatorname{OECD}(2013$, p. 17) has announced that it intends to develop recommendations regarding best practices in the design of rules to prevent base erosion through the use of interest payments by September 2015.
} 


\section{REFERENCES}

Altshuler, R., and H. Grubert, 2003, "Taxes, repatriation strategies and multinational financial policy," Journal of Public Economics, Vol. 87, pp. 73-107.

Auerbach, A.J., 2002, "Taxation and corporate financial policy." In A.J. Auerbach, and M. Feldstein, (eds.), Handbook of Public Economics, Volume III (New York: NorthHolland).

Brosens, L., 2004, “Thin capitalization rules and EU law,” EC Tax Review, Vol. 4, pp. 188-213.

Buettner, T., M. Overesch, U. Schreiber, and G. Wamser, 2012, "The impact of thincapitalization rules on the capital structure of multinational firms," Journal of Public Economics, Vol. 96, pp. 930-938.

DeAngelo, H., and R.W. Masulis, 1980, “Optimal capital structure under corporate and personal taxation," Journal of Financial Economics, Vol. 8, pp. 3-29.

Desai, M., F. Foley, and J. R. Hines, 2001, "Repatriation taxes and dividend distortions," National Tax Journal, Vol. 54, pp. 859-851.

— , 2004, "A multinational perspective on capital structure choice and internal capital markets," Journal of Finance, Vol. 59, pp. 2451-87.

Desai, M., and J.R. Hines, 1999, “'Basket' cases: Tax incentives and international joint venture participation by American multinational firms," Journal of Public Economics, Vol. 71, pp. 379-402.

Djankov, S., C. McLiesh, and A. Shleifer, 2007, "Private credit in 129 countries," Journal of Financial Economics, Vol. 84, pp. 299-329.

Froot, K.A., and J.R. Hines, 1995, "Interest allocation rules, financing patterns, and the operation of U.S. multinationals,” pp. 272-307. In M. Feldstein, J.R. Hines, R.G. Hubbard, (eds.), The Effect of Taxation on Multinational Corporations, (Chicago: University of Chicago Press).

Graham, J.R., 1996, "Debt and the marginal tax rate," Journal of Financial Economics, Vol. 41, pp. 41-73.

— 2000, "How big are the tax benefits of debt?," Journal of Finance, Vol. 55, pp. 19011941.

— 2003, "Taxes and corporate finance: A review," Review of Financial Studies, Vol. 16, pp. 1074-1128.

Graham, J.R., and C. Harvey, 2001, "The theory and practice of corporate finance: Evidence from the field," Journal of Financial Economics, Vol. 60, pp. 187-243.

Haufler, A., and M. Runkel, 2012, "Firms' financial choices and thin capitalization rules under corporate tax competition," European Economic Review, Vol. 56, pp. 1087-1103.

Hines, J., and E. Rice, 1994, "Fiscal paradise: Foreign tax havens and American business," Quarterly Journal of Economics, Vol. 109, pp. 149-182.

Huizinga, H., L. Laeven, and G. Nicodème, 2008, Capital structure and international debt shifting, Journal of Financial Economics 88, 80-118. 
MacKie-Mason, J., 1990, "Do taxes affect corporate financing decisions?," Journal of Finance, Vol. 45, pp. 1471-1493.

Mintz, J. and A. Weichenrieder, 2005, "Taxation and the financial structure of German outbound FDI," CESifo Working Paper No. 1612.

Myers, S.C., and N.S. Majluf, 1984, "Corporate financing and investment decisions when firms have information that investors do not have," Journal of Financial Economics, Vol. 13, pp. $187-221$.

Newberry, K.J., and D.S. Dhaliwal, 2001, "Cross-jurisdictional income shifting by U.S. multinationals: Evidence from international bond offerings," Journal of Accounting Research, Vol. 39, pp. 643-662.

OECD, 2013, Action Plan on Base Erosion and Profit Shifting, Paris.

Overesch, M., and G. Wamser, 2010, "Corporate tax planning and thin-capitalization rules: evidence from a quasi-experiment," Applied Economics, Vol. 42, pp. 563-573.

Rajan, R.G., and L. Zingales, 1995, "What do we know about capital structure? Some evidence from international data," Journal of Finance, Vol. 50, pp. 1421-60.

Wamser, G., 2008, "The impact of thin capitalization rules on external debt usage: a propensity score matching approach," CESifo Working Paper No. 62.

Weichenrieder, A., and H. Windischbauer, 2008, "Thin capitalization rules and company responses," CESifo Working Paper No. 2456. 


\section{Table 1. Characteristics of thin capitalization rules at year-end 2004}

This table shows key characteristics of thin capitalization rules in selected countries at year-end 2004. D denotes total debt; IID denotes single related party internal debt; TID denotes total internal debt; TIFD denotes total internal foreign debt; TFD denotes total foreign debt; $E$ denotes total equity; IIE denotes individual internal equity; TIE denotes total internal equity; TIFE denotes total internal foreign equity; TFE denotes total foreign equity; A denotes total assets; RoE denotes return on equity. Data are from International Bureau for Fiscal Documentation, Brosens (2004), and national tax authorities.

\begin{tabular}{|c|c|c|c|c|c|c|c|c|c|c|c|c|}
\hline & (1) & (2) & (3) & (4) & (5) & (6) & (7) & (8) & (9) & (10) & (11) & (12) \\
\hline $\begin{array}{l}\stackrel{\vec{E}}{\Xi} \\
\stackrel{\Xi}{0}\end{array}$ & 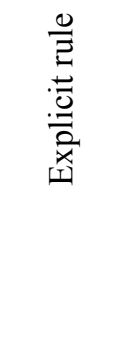 & 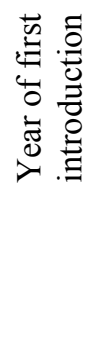 & 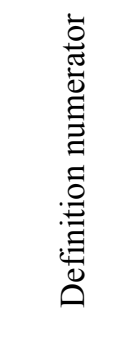 & 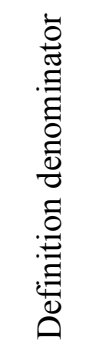 & 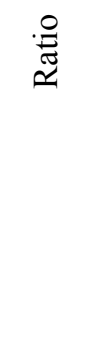 & 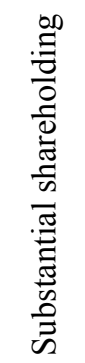 & 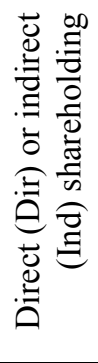 & 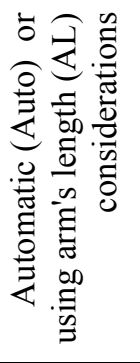 & 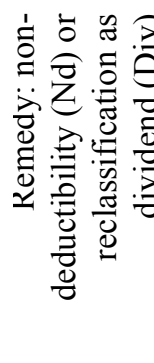 & 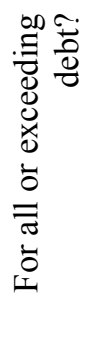 & 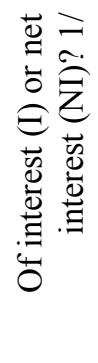 & 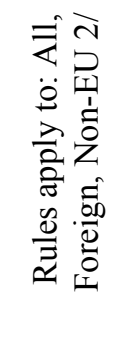 \\
\hline Argentina & Yes & 1999 & $\mathrm{D}$ & E & 2 & No & Dir & Auto & Div & Exc & I & Foreign \\
\hline $\begin{array}{l}\text { Australia } \\
\text { Austria }\end{array}$ & $\begin{array}{l}\text { Yes } \\
\mathrm{No}^{3 /}\end{array}$ & 1987 & $\mathrm{D}$ & $\mathrm{E}$ & 3 & $15 \%$ & Ind & $\mathrm{AL}$ & $\mathrm{Nd}$ & Exc & I & Foreign \\
\hline Belgium & Yes $^{4 /}$ & 1992 & IID & E & 1 & No & Dir & $\mathrm{AL}^{5 /}$ & Div & Exc & I & All \\
\hline $\begin{array}{l}\text { Brazil } \\
\text { Canada }\end{array}$ & No & 2010 & & & & & & & & & & \\
\hline Canada & Yes & 1972 & IID & IIE & 2 & $25 \%$ & Ind & Auto & $\mathrm{Nd}$ & Exc & I & Foreign \\
\hline Chile & Yes & 2001 & $\mathrm{D}$ & $\mathrm{E}$ & 3 & No & Dir & Auto & $\operatorname{Div}^{6 /}$ & Exc & I & All \\
\hline China & No & 2008 & & & & & & & & & & \\
\hline Colombia & No & & & & & & & & & & & \\
\hline Costa Rica & No & & & & & & & & & & & \\
\hline Croatia & No & & & & & & & & & & & \\
\hline Czech Republic & Yes & 1993 & TFD & E & $4^{7 /}$ & $25 \%$ & Ind & Auto & $\operatorname{Div}^{8 /}$ & Exc & I & Foreign \\
\hline $\begin{array}{l}\text { Denmark } \\
\text { Finland }\end{array}$ & $\begin{array}{l}\text { Yes } \\
\text { No }{ }^{10 /}\end{array}$ & 1999 & $\mathrm{D}^{9 /}$ & E & 4 & $50 \%$ & Ind & $\mathrm{AL}$ & $\mathrm{Nd}$ & Exc & I & All \\
\hline France & Yes & 1979 & IID & $\mathrm{E}$ & 1.5 & $50 \%$ & Dir & Auto & $\mathrm{Nd}$ & Exc & I & All \\
\hline Germany & Yes ${ }^{11 /}$ & 1994 & IID & IIE & 1.5 & $25 \%$ & Ind & $\mathrm{AL}$ & Div & Exc & I & All \\
\hline Greece & No & & & & & & & & & & & \\
\hline Hong Kong & $\mathrm{No}^{12 /}$ & & & & & & & & & & & \\
\hline Hungary & Yes & 1993 & $\mathrm{D}$ & E & 3 & No & Dir & Auto & $\mathrm{Nd}$ & Exc & I & All \\
\hline India & No & & & & & & & & & & & \\
\hline $\begin{array}{l}\text { Indonesia } \\
\text { Ireland }\end{array}$ & $\begin{array}{l}\text { Yes } \\
\text { No }{ }^{13 /}\end{array}$ & 1985 & $\mathrm{D}$ & E & 3 & No & Dir & $\mathrm{AL}$ & $\mathrm{Nd}$ & Exc & I & All \\
\hline Israel & No & & & & & & & & & & & \\
\hline Italy & Yes $^{14 /}$ & 2004 & IID & IIE & 5 & $25 \%$ & Ind & $\mathrm{AL}$ & Div & Exc & I & All \\
\hline Japan & Yes & 1992 & TIFD & TIFE & 3 & $50 \%$ & Ind & Auto ${ }^{15 /}$ & $\mathrm{Nd}$ & Exc & I & Foreign \\
\hline Latvia & Yes & 2003 & TID & E & 4 & No & Dir & Auto & $\mathrm{Nd}^{16 /}$ & All & I & All \\
\hline Lithuania & Yes & 2004 & $\mathrm{D}$ & E & 4 & $50 \%$ & Ind & $\mathrm{AL}$ & $\mathrm{Nd}$ & Exc & I & All \\
\hline Malaysia & No & & & & & & & & & & & \\
\hline Mexico & No & 2005 & & & & & & & & & & \\
\hline Netherlands & Yes & 2004 & $\mathrm{D}^{17 /}$ & $\mathrm{E}^{18 /}$ & 3 & $33 \%$ & Ind & Auto & $\mathrm{Nd}$ & Exc & NI & All \\
\hline New Zealand & Yes & 1996 & $\mathrm{D}$ & A & 0.75 & No & Dir & Auto & $\mathrm{Nd}$ & Exc & I & Foreign \\
\hline Norway & No & & & & & & & & & & & \\
\hline Pakistan & Yes & 2001 & TFD & TFE & 3 & $50 \%$ & Ind & Auto & $\mathrm{Nd}$ & Exc & I & Foreign \\
\hline Panama & No & & & & & & & & & & & \\
\hline Peru & Yes & 2001 & $\mathrm{D}$ & E & 3 & No & Dir & Auto & $\mathrm{Nd}$ & Exc & I & Foreign \\
\hline Philippines & No & & & & & & & & & & & \\
\hline Poland & Yes & 1999 & D & E & 3 & $25 \%$ & Ind & Auto & $\mathrm{Nd}$ & Exc & I & All \\
\hline Portugal & Yes & 1996 & TIDE $^{19 /}$ & TIFE & 2 & $10 \%$ & Ind & $\mathrm{AL}$ & $\mathrm{Nd}$ & Exc & I & Foreign \\
\hline
\end{tabular}




\begin{tabular}{|c|c|c|c|c|c|c|c|c|c|c|c|c|}
\hline Russia & Yes & 2002 & TIFD & $\mathrm{E}$ & 3 & $20 \%$ & Ind & Auto & Div & Exc & I & Foreign \\
\hline Singapore & No & & & & & & & & & & & \\
\hline Slovenia & Yes & 2004 & IID & IIE & 4 & $25 \%$ & Ind & Auto & $\mathrm{Nd}$ & Exc & I & All \\
\hline Slovakia & $\mathrm{No}^{20 /}$ & 1993 & & & & & & & & & & \\
\hline South Korea & Yes & 2000 & $\mathrm{D}$ & $\mathrm{E}$ & 4 & $50 \%$ & Ind & Auto & $\mathrm{Nd}$ & Exc & I & All \\
\hline Spain & Yes & 1992 & TIFD & E & 3 & $25 \%$ & Ind & Auto & Div & Exc & I & Non-EU \\
\hline Sri Lanka & No & 2006 & & & & & & & & & & \\
\hline Switzerland & Yes & 1962 & $\mathrm{D}$ & E & 6 & No & Dir & $\mathrm{AL}$ & Div & Exc & I & All \\
\hline Sweden & No & & & & & & & & & & & \\
\hline Taiwan & No & 2011 & & & & & & & & & & \\
\hline Thailand & No & & & & & & & & & & & \\
\hline Turkey & No & 2006 & & & & & & & & & & \\
\hline Ukraine & No & & & & & & & & & & & \\
\hline United & Yes & 1988 & $\mathrm{D}$ & E & 1 & $75 \%$ & Ind & $\mathrm{AL}$ & $\mathrm{Nd}$ & Exc & I & All \\
\hline Kingdom & & & & & & & & & & & & \\
\hline Venezuela & No & 2007 & & & & & & & & & & \\
\hline Vietnam & No & $2012^{21 /}$ & & & & & & & & & & \\
\hline United States 221 & Yes $^{23 /}$ & 1989 & $\mathrm{D}$ & $\mathrm{E}$ & 1.5 & $50 \%$ & Ind & $\mathrm{AL}^{24 /}$ & $\mathrm{Nd}$ & Exc & I & Foreign \\
\hline
\end{tabular}

Notes:

1/ Interest owed to affiliated entities minus interest received from these entities.

2/ Following the decision of the European Court of Justice in the Lankhorst-Hohorst case of 2003, members of the European Union are not allowed to discriminate between their national companies and other EU companies. From 2004, thin capitalization rules were either extended to domestic companies (Denmark, Germany, Italy, and United Kingdom) or repealed for EU companies (France, Spain).

$3 /$ General anti-abuse rules.

4/ The rule applies to loan from individual shareholder or director.

$5 /$ Consideration of the market rate.

6/ Sanction is higher taxation (35\% instead of $4 \%$ ).

7/ The ratio is 10 if foreign non-related party.

8/ Reclassification as dividend not explicit but taxation at same rate.

9/ Minimum threshold for controlled debt of DKK 10 million (about $€ 1.3$ million).

$10 /$ General anti-abuse rules with possible reclassification as dividend.

11/ Since 2008, Germany applies an earnings stripping rule.

12/ But general rule that all interest payment to foreign companies are not deductible.

$13 /$ General anti-abuse rules for non-EU companies. If indirect or direct shareholding is above $75 \%$, reclassification as dividend in certain cases.

14/ Except for holdings, companies with a turnover below $€ 5,164,569$ are not subject to the rules. Repealed in 2008 and replaced by earnings stripping rule.

15/ The ratio of total debt to third parties to total equity should be over 3 for the rule to apply.

16/ There is a general rule that limits interest deductibility to the value of equity times the interest rate on short-term loans.

However, it is possible to carry forward the interest expenses.

17/ Average net loans at start and end of period.

18 / Average fiscal equity at start and end of period.

$19 /$ With at least 6 months maturity.

20/ Thin capitalization rule repealed from 2004.

21/ Before, general non-deductibility if interest rate exceeded 1.5 times the one of Central Bank, while foreign companies had to respect a debt to equity ratio of 7 to 3 .

22/ US thin cap rules are presented for information only since we do not have any US-based affiliates in the sample.

23/ This ratio is a safe harbor provision.

24/ Fact and circumstances approach. The earning stripping rule also compares corporate income to interest paid to some nonresidents or to tax-exempt resident shareholders. The latter cannot be higher than $50 \%$ of the former. 


\section{Table 2. Descriptive statistics and correlations}

This table provides summary statistics and correlations for the main regression variables. Panel A reports descriptive statistics for the affiliate level variables, panel B reports descriptive statistics for the aggregate firm level variables, and panel C reports the correlation matrix for the affiliate level variables. Total leverage is the ratio of total US foreign affiliate debt to affiliate assets. Internal leverage is the ratio of internal debt owed to the parent to affiliate equity. Internal debt share is the ratio of internal debt owed to the parent to total affiliate debt. Country tax rate is the median tax rate in the affiliate host country estimated annually using affiliate-level tax burdens. Thin cap restriction is a dummy variable that equals 1 if a country has a thin capitalization rule and zero otherwise. Total leverage restriction is a dummy variable that equals 1 if a country imposes a quantitative restriction on the ratio of total debt to assets and zero otherwise. Internal leverage restriction is a dummy variable that equals 1 if a country imposes a quantitative restriction on the ratio of internal debt to the sum of internal debt and internal equity. Total leverage ratio is the maximum ratio of total debt to assets. Internal leverage ratio is the maximum ratio of internal debt to sum of internal debt and internal equity. Arm's length is application of remedy following arm's length considerations. Net PPE/assets is the ratio of net property, plant and equipment to assets in the affiliate. EBITDA/assets is the ratio of earnings before interest, depreciation and amortization to assets. Log of sales is the logarithm of sales. Creditor rights is an index of creditor rights from Djankov, McLiesh and Shleifer (2007). Political risk is the annual index of political risk from the International Country Risk Guide. Rate of inflation is the annual percentage in the consumer price index from the World Development Indicators. Growth options is the compound annual growth rate of total affiliate sales at the industry and country level. Tobin's $q$ is the ratio of the market value of the overall firm's equity plus debt to total assets. Industry-adjusted Tobin's $q$ is Tobin's q minus the firm's industry mean Tobin's q. Aggregate debt is the ratio of total debt to total assets of the consolidated multinational firm estimated using Compustat data. Aggregate interest expense is the ratio of interest expenses to total assets of the consolidated multinational firm. Aggregate interest expense to debt is the ratio of interest expenses to total debt of the consolidated multinational firm. Aggregate thin cap restriction is the ratio of the sum of the assets of foreign affiliates subject to a thin cap restriction to the total assets of the consolidated multinational firm. Aggregate total leverage restriction is the ratio of the sum of the assets of foreign affiliates subject to a total leverage restriction to the total assets of the consolidated multinational firm. Aggregate internal leverage restriction is the ratio of the sum of the assets of foreign affiliates subject to an internal leverage restriction to the total assets of the consolidated multinational firm. Note that all medians represent the average of the five median observations for the five benchmark years.

Panel A. Descriptive statistics of main regression variables in affiliate level regressions

\begin{tabular}{|c|c|c|c|c|}
\hline Variable & $\mathrm{N}$ & Mean & Median & Std. dev. \\
\hline Total leverage & 54,269 & 0.552 & 0.502 & 0.420 \\
\hline Internal leverage & 52,092 & 0.154 & 0.000 & 1.884 \\
\hline Internal debt share & 51,524 & 0.084 & 0.003 & 0.352 \\
\hline Country tax rate & 54,273 & 0.299 & 0.314 & 0.110 \\
\hline Thin cap restriction & 54,273 & 0.581 & 1.000 & 0.493 \\
\hline Total leverage restriction & 54,273 & 0.252 & 0.000 & 0.434 \\
\hline Internal leverage restriction & 54,273 & 0.328 & 0.000 & 0.470 \\
\hline Total leverage ratio & 54,273 & 0.904 & 1.000 & 0.178 \\
\hline Internal leverage ratio & 54,273 & 0.895 & 1.000 & 0.157 \\
\hline Arm's length & 54,273 & 0.236 & 0.000 & 0.424 \\
\hline Net PPE/assets & 54,273 & 0.202 & 0.115 & 0.230 \\
\hline EBITDA/assets & 54,273 & 0.122 & 0.101 & 0.231 \\
\hline Log of sales & 54,273 & 9.884 & 10.247 & 2.735 \\
\hline Creditor rights & 54,273 & 2.199 & 2.000 & 1.265 \\
\hline Political risk & 54,273 & 0.792 & 0.810 & 0.095 \\
\hline Rate of inflation & 54,273 & 0.121 & 0.018 & 0.963 \\
\hline Growth options & 54,273 & 0.103 & 0.078 & 0.203 \\
\hline
\end{tabular}

Panel B. Descriptive statistics of main regression variables in aggregate firm level regressions

\begin{tabular}{lcccc}
\hline Variable & $\mathrm{N}$ & Mean & Median & Std. dev. \\
\hline Tobin's q & 4,558 & 1.349 & 1.015 & 1.257 \\
Industry-adjusted Tobin's q & 4,558 & -0.236 & -0.253 & 1.222 \\
Aggregate debt & 4,558 & 0.253 & 0.232 & 0.190 \\
Aggregate interest expense & 9,705 & 0.023 & 0.017 & 0.022 \\
Aggregate interest expense to debt & 9,705 & 0.111 & 0.055 & 0.199 \\
\hline
\end{tabular}




\begin{tabular}{|c|c|c|c|c|}
\hline Variable & $\mathrm{N}$ & Mean & Median & Std. dev \\
\hline Aggregate thin cap restriction & 9,705 & 0.156 & 0.097 & 0.186 \\
\hline Aggregate total leverage restriction & 9,705 & 0.062 & 0.010 & 0.113 \\
\hline Aggregate internal leverage restriction & 9,705 & 0.091 & 0.042 & 0.139 \\
\hline Net PPE/assets & 9,705 & 0.267 & 0.231 & 0.187 \\
\hline EBITDA/assets & 9,705 & 0.126 & 0.115 & 0.124 \\
\hline Log of sales & 9,705 & 13.115 & 13.042 & 1.861 \\
\hline Creditor rights & 9,705 & 2.279 & 2.254 & 1.010 \\
\hline Political risk & 9,705 & 0.807 & 0.812 & 0.066 \\
\hline Rate of inflation & 9,705 & 0.088 & 0.023 & 0.534 \\
\hline Growth options & 9,705 & 0.089 & 0.074 & 0.114 \\
\hline
\end{tabular}


Panel C. Correlation matrix of main regression variables

\begin{tabular}{|c|c|c|c|c|c|c|c|c|c|c|c|c|c|}
\hline & $\begin{array}{l}\text { Total } \\
\text { leverage }\end{array}$ & $\begin{array}{l}\text { Internal } \\
\text { leverage }\end{array}$ & $\begin{array}{l}\text { Internal } \\
\text { debt share }\end{array}$ & $\begin{array}{l}\text { Country } \\
\text { tax rate }\end{array}$ & $\begin{array}{l}\text { Thin cap } \\
\text { restriction }\end{array}$ & $\begin{array}{l}\text { Total } \\
\text { leverage } \\
\text { restriction }\end{array}$ & $\begin{array}{l}\text { Internal } \\
\text { leverage } \\
\text { restriction }\end{array}$ & $\begin{array}{l}\text { Net PPE/ } \\
\text { assets }\end{array}$ & $\begin{array}{l}\text { EBITDA/ } \\
\text { assets }\end{array}$ & $\begin{array}{l}\text { Log of } \\
\text { sales }\end{array}$ & $\begin{array}{l}\text { Creditor } \\
\text { rights }\end{array}$ & $\begin{array}{l}\text { Political } \\
\text { risk }\end{array}$ & $\begin{array}{l}\text { Rate of } \\
\text { inflation }\end{array}$ \\
\hline Internal leverage & -0.057 & & & & & & & & & & & & \\
\hline Internal debt share & 0.238 & 0.416 & & & & & & & & & & & \\
\hline Country tax rate & 0.068 & 0.067 & 0.060 & & & & & & & & & & \\
\hline Thin cap restriction & -0.042 & -0.011 & -0.004 & 0.095 & & & & & & & & & \\
\hline Total leverage restriction & -0.024 & -0.020 & -0.017 & -0.224 & 0.569 & & & & & & & & \\
\hline Internal leverage restriction & -0.025 & 0.008 & 0.012 & 0.331 & 0.577 & -0.343 & & & & & & & \\
\hline Net PPE/assets & 0.003 & 0.016 & 0.062 & 0.032 & -0.046 & -0.061 & 0.008 & & & & & & \\
\hline EBITDA/assets & -0.262 & 0.045 & -0.102 & 0.002 & -0.024 & -0.028 & 0.000 & 0.044 & & & & & \\
\hline Log of sales & 0.072 & 0.053 & -0.050 & 0.099 & 0.003 & -0.072 & 0.075 & 0.176 & 0.156 & & & & \\
\hline Creditor rights & 0.022 & -0.001 & -0.000 & -0.131 & 0.318 & 0.410 & -0.044 & -0.071 & -0.021 & -0.058 & & & \\
\hline Political risk & -0.018 & -0.002 & -0.025 & 0.132 & 0.395 & 0.220 & 0.233 & -0.151 & -0.016 & -0.017 & 0.265 & & \\
\hline Rate of inflation & -0.020 & -0.002 & 0.011 & 0.024 & -0.103 & -0.057 & -0.062 & 0.057 & 0.045 & 0.014 & -0.108 & -0.171 & \\
\hline Growth options & -0.049 & -0.017 & -0.013 & -0.182 & 0.025 & 0.132 & -0.103 & -0.083 & -0.022 & -0.247 & 0.031 & 0.050 & -0.016 \\
\hline
\end{tabular}




\section{Table 3. The introduction of thin capitalization rules and borrowing}

This table provides mean values of the Total leverage and Internal leverage variables before and after the introduction of a restriction on total leverage (in Panel A) and on internal leverage (in Panel B). Total leverage is the ratio of total US foreign affiliate debt to affiliate assets. Internal leverage is the ratio of internal debt owed to the parent to affiliate equity. ${ }^{*}, * *, * * *$ indicate that ex post mean value of a variable is statistically significantly different from the ex ante mean value at the $10 \%, 5 \%$ and $1 \%$ levels, respectively.

Panel A. Restrictions on total leverage

\begin{tabular}{lrrrlll}
\hline & \multicolumn{2}{l}{ Number of observations } & \multicolumn{2}{l}{ Total leverage } & \multicolumn{2}{c}{ Internal leverage } \\
Country & Before & After & Before & After & Before & After \\
\hline Argentina & 294 & 526 & 0.539 & 0.523 & 0.105 & 0.098 \\
Australia & 569 & 632 & 0.635 & $0.495^{* * *}$ & 0.201 & $0.061^{* * *}$ \\
Chile & 258 & 128 & 0.500 & $0.449^{* *}$ & 0.104 & $0.039^{* *}$ \\
Denmark & 202 & 335 & 0.660 & $0.573^{* *}$ & 0.077 & $0.035^{* *}$ \\
Netherlands & 2063 & 832 & 0.557 & $0.503^{* * *}$ & 0.064 & $0.031^{* * *}$ \\
New Zealand & 175 & 266 & 0.567 & 0.525 & 0.136 & $0.095^{*}$ \\
South Korea & 326 & 228 & 0.524 & $0.436^{* * *}$ & 0.049 & 0.037 \\
United Kingdom & 1430 & 5984 & 0.624 & $0.552^{* * *}$ & 0.142 & $0.063^{* * *}$ \\
\hline Average & & & 0.582 & 0.537 & 0.106 & 0.061 \\
\hline
\end{tabular}

Panel B. Restrictions on internal leverage

\begin{tabular}{lcccccl}
\hline & \multicolumn{2}{l}{$\begin{array}{l}\text { Number of observations } \\
\text { Before }\end{array}$} & After & \multicolumn{2}{l}{ Total leverage } & \multicolumn{2}{l}{ Internal leverage } \\
Before & After & Before & After \\
\hline Australia & 569 & 1308 & 0.636 & $0.578^{* * *}$ & 0.201 & $0.086^{* * *}$ \\
Belgium & 688 & 1071 & 0.607 & $0.561^{* * *}$ & 0.075 & $0.045^{* * *}$ \\
Germany & 611 & 2654 & 0.595 & $0.560^{* *}$ & 0.063 & 0.056 \\
Italy & 1606 & 536 & 0.620 & $0.543^{* * *}$ & 0.060 & $0.025^{* * *}$ \\
Japan & 607 & 1801 & 0.689 & $0.640^{* * *}$ & 0.127 & $0.075^{* * *}$ \\
Portugal & 142 & 262 & 0.628 & 0.580 & 0.080 & $0.042^{* *}$ \\
Spain & 479 & 1061 & 0.605 & $0.532^{* * *}$ & 0.066 & $0.029^{* * *}$ \\
\hline Average & & & 0.624 & 0.578 & 0.090 & 0.057 \\
\hline
\end{tabular}




\section{Table 4. Thin capitalization restrictions on total debt and total borrowing by US affiliates}

The dependent variable is Total leverage which is the ratio of total US foreign affiliate debt to affiliate assets. Country tax rate is the median tax rate in the affiliate host country estimated annually using affiliate-level tax burdens. Thin cap restriction is a dummy variable that equals 1 if a country has a thin capitalization rule and zero otherwise. Total leverage restriction is a dummy variable that equals 1 if a country imposes a quantitative restriction on the ratio of total debt to assets and zero otherwise. Total leverage ratio is the maximum allowable ratio of total debt to assets. Net PPE/assets is the ratio of net property, plant and equipment to assets in the affiliate. EBITDA/assets is the ratio of earnings before interest, depreciation and amortization to assets. Log of sales is the logarithm of sales. Creditor rights is an index of creditor rights from Djankov, McLiesh and Shleifer (2007). Political risk is the annual index of political risk from the International Country Risk Guide. Rate of inflation is the annual percentage in the consumer price index from the World Development Indicators. Growth options is the compound annual growth rate of total affiliate sales at the industry and country level. Regressions include parent, industry and year fixed effects, and standard errors correct for clustering across observations in country/industry cells. *, **, and $* * *$ denote significance at the $10 \%, 5 \%$, and $1 \%$ levels, respectively.

\begin{tabular}{|c|c|c|c|c|c|c|c|}
\hline VARIABLES & (1) & $(2)$ & (3) & $(4)$ & $(5)$ & $(6)$ & $(7)$ \\
\hline Country tax rate & $\begin{array}{l}0.197 * * * \\
(0.0353)\end{array}$ & $\begin{array}{l}0.223 * * * \\
(0.0324)\end{array}$ & $\begin{array}{l}0.217 * * * \\
(0.0347)\end{array}$ & $\begin{array}{l}0.187 * * * \\
(0.0322)\end{array}$ & $\begin{array}{l}0.174 * * * \\
(0.0325)\end{array}$ & $\begin{array}{l}0.193 * * * \\
(0.0339)\end{array}$ & $\begin{array}{l}0.493 * * * \\
(0.166)\end{array}$ \\
\hline Thin cap restriction & & $\begin{array}{l}-0.0214 * * * \\
(0.00747)\end{array}$ & $\begin{array}{l}-0.0272 \\
(0.0214)\end{array}$ & & & & \\
\hline $\begin{array}{l}\text { Country tax rate } \times \\
\text { Thin cap restriction }\end{array}$ & & & $\begin{array}{c}0.0183 \\
(0.0744)\end{array}$ & & & & \\
\hline Total leverage restriction & & & & $\begin{array}{c}-0.0186 * * * \\
(0.00691)\end{array}$ & $\begin{array}{l}-0.0445^{* *} \\
(0.0195)\end{array}$ & & \\
\hline $\begin{array}{l}\text { Country tax rate } \times \\
\text { Total leverage restriction }\end{array}$ & & & & & $\begin{array}{c}0.0978 \\
(0.0661)\end{array}$ & & \\
\hline Total leverage ratio & & & & & & $\begin{array}{l}0.0307^{*} \\
(0.0184)\end{array}$ & $\begin{array}{l}0.119^{* *} \\
(0.0555)\end{array}$ \\
\hline $\begin{array}{l}\text { Country tax rate } \times \\
\text { Total leverage ratio }\end{array}$ & & & & & & & $\begin{array}{l}-0.313^{*} \\
(0.169)\end{array}$ \\
\hline Net PPE/assets & $\begin{array}{c}0.0329 * * \\
(0.0138)\end{array}$ & $\begin{array}{c}0.0331 * * \\
(0.0138)\end{array}$ & $\begin{array}{c}0.0331 * * \\
(0.0138)\end{array}$ & $\begin{array}{c}0.0333 * * \\
(0.0138)\end{array}$ & $\begin{array}{c}0.0328 * * \\
(0.0138)\end{array}$ & $\begin{array}{c}0.0333 * * \\
(0.0138)\end{array}$ & $\begin{array}{l}0.0329 * * \\
(0.0138)\end{array}$ \\
\hline EBITDA/assets & $\begin{array}{c}-0.469 * * * \\
(0.0221)\end{array}$ & $\begin{array}{l}-0.470 * * * \\
(0.0221)\end{array}$ & $\begin{array}{l}-0.470 * * * \\
(0.0221)\end{array}$ & $\begin{array}{l}-0.470 * * * \\
(0.0221)\end{array}$ & $\begin{array}{c}-0.470 * * * \\
(0.0221)\end{array}$ & $\begin{array}{c}-0.470 * * * \\
(0.0221)\end{array}$ & $\begin{array}{c}-0.470^{* * * *} \\
(0.0222)\end{array}$ \\
\hline Log of sales & $\begin{array}{c}0.616^{* * *} \\
(0.220)\end{array}$ & $\begin{array}{c}0.638 * * * \\
(0.218)\end{array}$ & $\begin{array}{c}0.637 * * * \\
(0.219)\end{array}$ & $\begin{array}{c}0.622 * * * \\
(0.219)\end{array}$ & $\begin{array}{c}0.620 * * * \\
(0.219)\end{array}$ & $\begin{array}{c}0.623 * * * \\
(0.219)\end{array}$ & $\begin{array}{c}0.620 * * * \\
(0.218)\end{array}$ \\
\hline Creditor rights & $\begin{array}{l}0.0084 * * * \\
(0.00305)\end{array}$ & $\begin{array}{l}0.0089 * * * \\
(0.00329)\end{array}$ & $\begin{array}{l}0.0090 * * * \\
(0.00315)\end{array}$ & $\begin{array}{l}0.0107 * * * \\
(0.00322)\end{array}$ & $\begin{array}{l}0.0099 * * * \\
(0.00317)\end{array}$ & $\begin{array}{l}0.0105^{* * *} \\
(0.00356)\end{array}$ & $\begin{array}{l}0.0101 * * * \\
(0.00346)\end{array}$ \\
\hline Political risk & $\begin{array}{c}-0.200^{* * *} \\
(0.0356)\end{array}$ & $\begin{array}{c}-0.173 * * * \\
(0.0322)\end{array}$ & $\begin{array}{c}-0.171^{* * *} \\
(0.0336)\end{array}$ & $\begin{array}{c}-0.189 * * * \\
(0.0346)\end{array}$ & $\begin{array}{l}-0.178^{* * *} \\
(0.0340)\end{array}$ & $\begin{array}{c}-0.195 * * * \\
(0.0351)\end{array}$ & $\begin{array}{c}-0.186 * * * \\
(0.0339)\end{array}$ \\
\hline Rate of inflation & $\begin{array}{c}-0.376^{* * *} \\
(0.0970)\end{array}$ & $\begin{array}{c}-0.434 * * * \\
(0.0980)\end{array}$ & $\begin{array}{c}-0.426 * * * \\
(0.0999)\end{array}$ & $\begin{array}{c}-0.359 * * * \\
(0.0967)\end{array}$ & $\begin{array}{c}-0.346 * * * \\
(0.0970)\end{array}$ & $\begin{array}{c}-0.363 * * * \\
(0.0978)\end{array}$ & $\begin{array}{c}-0.346 * * * \\
(0.0988)\end{array}$ \\
\hline Growth options & $\begin{array}{l}0.00331 \\
(0.0147)\end{array}$ & $\begin{array}{l}0.00220 \\
(0.0121)\end{array}$ & $\begin{array}{l}0.00242 \\
(0.0120)\end{array}$ & $\begin{array}{l}0.00561 \\
(0.0137)\end{array}$ & $\begin{array}{l}0.00640 \\
(0.0130)\end{array}$ & $\begin{array}{l}0.00328 \\
(0.0142)\end{array}$ & $\begin{array}{l}0.00312 \\
(0.0133)\end{array}$ \\
\hline Observations & 54,269 & 54,269 & 54,269 & 54,269 & 54,269 & 54,269 & 54,269 \\
\hline R-squared & 0.097 & 0.097 & 0.097 & 0.097 & 0.097 & 0.097 & 0.097 \\
\hline Number of parents & 3,943 & 3,943 & 3,943 & 3,943 & 3,943 & 3,943 & 3,943 \\
\hline
\end{tabular}




\section{Table 5. Thin capitalization restrictions on internal debt and borrowing from the parent relative to equity}

The dependent variable is Internal leverage which is the ratio of internal debt owed to the parent to affiliate equity. Country tax rate is the median tax rate in the affiliate host country estimated annually using affiliate-level tax burdens. Thin cap restriction is a dummy variable that equals 1 if a country has a thin capitalization rule and zero otherwise. Internal leverage restriction is a dummy variable that equals 1 if a country imposes a quantitative restriction on the ratio of internal debt to the sum of internal debt and internal equity. Internal leverage ratio is the maximum allowable ratio of internal debt to sum of internal debt and internal equity. Net PPE/assets is the ratio of net property, plant and equipment to assets in the affiliate. EBITDA/assets is the ratio of earnings before interest, depreciation and amortization to assets. Log of sales is the logarithm of sales. Creditor rights is an index of creditor rights from Djankov, McLiesh and Shleifer (2007). Political risk is the annual index of political risk from the International Country Risk Guide. Rate of inflation is the annual percentage in the consumer price index from the World Development Indicators. Growth options is the compound annual growth rate of total affiliate sales at the industry, and country level. Regressions include parent, industry, and year fixed effects, and standard errors correct for clustering across observations in country/industry cells. $*, * *$, and $* * *$ denote significance at the $10 \%, 5 \%$, and $1 \%$ levels, respectively.

\begin{tabular}{|c|c|c|c|c|c|c|c|}
\hline VARIABLES & (1) & $(2)$ & (3) & (4) & $(5)$ & (6) & (7) \\
\hline Country tax rate & $\begin{array}{l}0.368 * * * \\
(0.0981)\end{array}$ & $\begin{array}{l}0.468 * * * \\
(0.0942)\end{array}$ & $\begin{array}{l}0.468 * * * \\
(0.111)\end{array}$ & $\begin{array}{l}0.479 * * * \\
(0.103)\end{array}$ & $\begin{array}{l}0.480 * * * \\
(0.108)\end{array}$ & $\begin{array}{l}0.465 * * * \\
(0.102)\end{array}$ & $\begin{array}{c}0.229 \\
(0.559)\end{array}$ \\
\hline Thin cap restriction & & $\begin{array}{c}-0.0800 * * * \\
(0.0180)\end{array}$ & $\begin{array}{l}-0.0806 \\
(0.0611)\end{array}$ & & & & \\
\hline $\begin{array}{l}\text { Country tax rate } \times \\
\text { Thin cap restriction }\end{array}$ & & & $\begin{array}{c}0.00182 \\
(0.186)\end{array}$ & & & & \\
\hline Internal leverage restriction & & & & $\begin{array}{c}-0.0629 * * * \\
(0.0224)\end{array}$ & $\begin{array}{l}-0.0602 \\
(0.0682)\end{array}$ & & \\
\hline $\begin{array}{l}\text { Country tax rate } \times \\
\text { Internal leverage restriction }\end{array}$ & & & & & $\begin{array}{c}-0.00793 \\
(0.198)\end{array}$ & & \\
\hline Internal leverage ratio & & & & & & $\begin{array}{l}0.196 * * * \\
(0.0603)\end{array}$ & $\begin{array}{l}0.115 \\
(0.184)\end{array}$ \\
\hline $\begin{array}{l}\text { Country tax rate } \times \\
\text { Internal leverage ratio }\end{array}$ & & & & & & & $\begin{array}{l}0.246 \\
(0.589)\end{array}$ \\
\hline Net PPE/assets & $\begin{array}{l}-0.0751 \\
(0.0501)\end{array}$ & $\begin{array}{l}-0.0743 \\
(0.0503)\end{array}$ & $\begin{array}{l}-0.0743 \\
(0.0503)\end{array}$ & $\begin{array}{l}-0.0761 \\
(0.0503)\end{array}$ & $\begin{array}{l}-0.0761 \\
(0.0502)\end{array}$ & $\begin{array}{l}-0.0777 \\
(0.0503)\end{array}$ & $\begin{array}{l}-0.0780 \\
(0.0502)\end{array}$ \\
\hline EBITDA/assets & $\begin{array}{c}0.0971 * * * \\
(0.0355)\end{array}$ & $\begin{array}{l}0.0943 * * * \\
(0.0355)\end{array}$ & $\begin{array}{c}0.0943 * * * \\
(0.0355)\end{array}$ & $\begin{array}{c}0.0963 * * * \\
(0.0355)\end{array}$ & $\begin{array}{c}0.0963 * * * \\
(0.0355)\end{array}$ & $\begin{array}{c}0.0952 * * * \\
(0.0355)\end{array}$ & $\begin{array}{c}0.0953 * * * \\
(0.0355)\end{array}$ \\
\hline Log of sales & $\begin{array}{c}1.871 * * * \\
(0.496)\end{array}$ & $\begin{array}{l}1.952 * * * \\
(0.502)\end{array}$ & $\begin{array}{l}1.952 * * * \\
(0.501)\end{array}$ & $\begin{array}{l}1.919 * * * \\
(0.500)\end{array}$ & $\begin{array}{l}1.919 * * * \\
(0.500)\end{array}$ & $\begin{array}{c}1.925 * * * \\
(0.501)\end{array}$ & $\begin{array}{c}1.926 * * * \\
(0.501)\end{array}$ \\
\hline Creditor rights & $\begin{array}{l}0.00619 \\
(0.0079)\end{array}$ & $\begin{array}{l}0.00819 \\
(0.0073)\end{array}$ & $\begin{array}{l}0.00820 \\
(0.0075)\end{array}$ & $\begin{array}{l}0.00001 \\
(0.0083)\end{array}$ & $\begin{array}{l}0.00000 \\
(0.0084)\end{array}$ & $\begin{array}{l}-0.00183 \\
(0.0085)\end{array}$ & $\begin{array}{r}-0.00233 \\
(0.0087)\end{array}$ \\
\hline Political risk & $\begin{array}{l}-0.179 \\
(0.117)\end{array}$ & $\begin{array}{r}-0.0765 \\
(0.111)\end{array}$ & $\begin{array}{r}-0.0763 \\
(0.113)\end{array}$ & $\begin{array}{c}-0.135 \\
(0.118)\end{array}$ & $\begin{array}{c}-0.135 \\
(0.118)\end{array}$ & $\begin{array}{c}-0.132 \\
(0.119)\end{array}$ & $\begin{array}{l}-0.130 \\
(0.119)\end{array}$ \\
\hline Rate of inflation & $\begin{array}{c}-2.301^{* * *} \\
(0.750)\end{array}$ & $\begin{array}{c}-2.517 * * * \\
(0.754)\end{array}$ & $\begin{array}{c}-2.516^{* * *} \\
(0.758)\end{array}$ & $\begin{array}{c}-2.529^{* * *} \\
(0.758)\end{array}$ & $\begin{array}{c}-2.530^{* * * *} \\
(0.760)\end{array}$ & $\begin{array}{c}-2.537 * * * \\
(0.758)\end{array}$ & $\begin{array}{c}-2.556 * * * \\
(0.762)\end{array}$ \\
\hline Growth options & $\begin{array}{l}-0.0337 \\
(0.0389)\end{array}$ & $\begin{array}{l}-0.0377 \\
(0.0309)\end{array}$ & $\begin{array}{l}-0.0377 \\
(0.0309)\end{array}$ & $\begin{array}{l}-0.0446 \\
(0.0366)\end{array}$ & $\begin{array}{l}-0.0445 \\
(0.0367)\end{array}$ & $\begin{array}{c}-0.0453 \\
(0.0365)\end{array}$ & $\begin{array}{l}-0.0445 \\
(0.0365)\end{array}$ \\
\hline Observations & 52,092 & 52,092 & 52,092 & 52,092 & 52,092 & 52,092 & 52,092 \\
\hline R-squared & 0.003 & 0.003 & 0.003 & 0.003 & 0.003 & 0.003 & 0.003 \\
\hline Number of parents & 3,868 & 3,868 & 3,868 & 3,868 & 3,868 & 3,868 & 3,868 \\
\hline
\end{tabular}




\section{Table 6. Thin capitalization restrictions on the share of internal debt and borrowing from the parent}

The dependent variable is the Internal debt share which is the ratio of internal debt owed to the parent to total affiliate debt. Country tax rate is the median tax rate in the affiliate host country estimated annually using affiliate-level tax burdens. Thin cap restriction is a dummy variable that equals 1 if a country has a thin capitalization rule and zero otherwise. Internal leverage restriction is a dummy variable that equals 1 if a country imposes a quantitative restriction on the ratio of internal debt to the sum of internal debt and internal equity. Internal leverage ratio is the maximum ratio of internal debt to sum of internal debt and internal equity. Net PPE/assets is the ratio of net property, plant and equipment to assets in the affiliate. EBITDA/assets is the ratio of earnings before interest, depreciation and amortization to assets. Log of sales is the logarithm of sales. Creditor rights is an index of creditor rights from Djankov, McLiesh and Shleifer (2007). Political risk is the annual index of political risk from the International Country Risk Guide. Rate of inflation is the annual percentage in the consumer price index from the World Development Indicators. Growth options is the compound annual growth rate of total affiliate sales at the industry, and country level. Regressions include parent, industry, and year fixed effects, and standard errors correct for clustering across observations in country/industry cells. $*, * *$, and $* * *$ denote significance at the $10 \%, 5 \%$, and $1 \%$ levels, respectively.

\begin{tabular}{|c|c|c|c|c|c|c|c|}
\hline VARIABLES & $(1)$ & $(2)$ & (3) & (4) & (5) & (6) & $(7)$ \\
\hline Country tax rate & $\begin{array}{l}0.117 * * * \\
(0.0330)\end{array}$ & $\begin{array}{l}0.130 * * * \\
(0.0339)\end{array}$ & $\begin{array}{l}0.104 * * * \\
(0.0307)\end{array}$ & $\begin{array}{l}0.131 * * * \\
(0.0339)\end{array}$ & $\begin{array}{l}0.130 * * * \\
(0.0348)\end{array}$ & $\begin{array}{l}0.136^{* * *} \\
(0.0338)\end{array}$ & $\begin{array}{c}0.195 \\
(0.165)\end{array}$ \\
\hline Thin cap restriction & & $\begin{array}{l}-0.0103 * \\
(0.00616)\end{array}$ & $\begin{array}{c}-0.0348 * * \\
(0.0177)\end{array}$ & & & & \\
\hline $\begin{array}{l}\text { Country tax rate } \times \\
\text { Thin cap restriction }\end{array}$ & & & $\begin{array}{c}0.0786 \\
(0.0538)\end{array}$ & & & & \\
\hline Internal leverage restriction & & & & $\begin{array}{l}-0.00781 \\
(0.00733)\end{array}$ & $\begin{array}{l}-0.0102 \\
(0.0211)\end{array}$ & & \\
\hline $\begin{array}{l}\text { Country tax rate } \times \\
\text { Internal leverage restriction }\end{array}$ & & & & & $\begin{array}{l}0.00686 \\
(0.0604)\end{array}$ & & \\
\hline Internal leverage ratio & & & & & & $\begin{array}{l}0.0374 * \\
(0.0202)\end{array}$ & $\begin{array}{c}0.0576 * * \\
(0.0249)\end{array}$ \\
\hline $\begin{array}{l}\text { Country tax rate } \times \\
\text { Internal leverage ratio }\end{array}$ & & & & & & & $\begin{array}{l}-0.0615^{*} \\
(0.0337)\end{array}$ \\
\hline Net PPE/assets & $\begin{array}{l}0.107 * * * \\
(0.0129)\end{array}$ & $\begin{array}{l}0.107 * * * \\
(0.0130)\end{array}$ & $\begin{array}{l}0.107 * * * \\
(0.0129)\end{array}$ & $\begin{array}{l}0.107 * * * \\
(0.0130)\end{array}$ & $\begin{array}{l}0.107 * * * \\
(0.0130)\end{array}$ & $\begin{array}{l}0.107 * * * \\
(0.0130)\end{array}$ & $\begin{array}{l}0.107 * * * \\
(0.0130)\end{array}$ \\
\hline EBITDA/assets & $\begin{array}{l}-0.121 * * * \\
(0.00882)\end{array}$ & $\begin{array}{l}-0.121 * * * \\
(0.00881)\end{array}$ & $\begin{array}{l}-0.121^{* * *} \\
(0.00882)\end{array}$ & $\begin{array}{l}-0.121^{* * *} \\
(0.00882)\end{array}$ & $\begin{array}{r}-0.121 * * * \\
(0.00881)\end{array}$ & $\begin{array}{l}-0.121 * * * \\
(0.00882)\end{array}$ & $\begin{array}{r}-0.121 * * * \\
(0.00881)\end{array}$ \\
\hline Log of sales & $\begin{array}{c}-0.262 * * \\
(0.115)\end{array}$ & $\begin{array}{c}-0.251 * * \\
(0.117)\end{array}$ & $\begin{array}{c}-0.255^{* *} \\
(0.116)\end{array}$ & $\begin{array}{c}-0.255^{* *} \\
(0.114)\end{array}$ & $\begin{array}{c}-0.256^{* *} \\
(0.114)\end{array}$ & $\begin{array}{c}-0.251 * * \\
(0.115)\end{array}$ & $\begin{array}{c}-0.251 * * \\
(0.115)\end{array}$ \\
\hline Creditor rights & $\begin{array}{c}0.00302 \\
(0.00280)\end{array}$ & $\begin{array}{c}0.00327 \\
(0.00274)\end{array}$ & $\begin{array}{c}0.00357 \\
(0.00271)\end{array}$ & $\begin{array}{c}0.00226 \\
(0.00282)\end{array}$ & $\begin{array}{c}0.00228 \\
(0.00282)\end{array}$ & $\begin{array}{c}0.00148 \\
(0.00290)\end{array}$ & $\begin{array}{c}0.00161 \\
(0.00294)\end{array}$ \\
\hline Political risk & $\begin{array}{c}-0.162 * * * \\
(0.0336)\end{array}$ & $\begin{array}{c}-0.149 * * * \\
(0.0307)\end{array}$ & $\begin{array}{c}-0.140 * * * \\
(0.0298)\end{array}$ & $\begin{array}{c}-0.157 * * * \\
(0.0336)\end{array}$ & $\begin{array}{c}-0.157 * * * \\
(0.0335)\end{array}$ & $\begin{array}{c}-0.153 * * * \\
(0.0342)\end{array}$ & $\begin{array}{c}-0.154^{* * *} \\
(0.0340)\end{array}$ \\
\hline Rate of inflation & $\begin{array}{c}0.300^{* *} \\
(0.120)\end{array}$ & $\begin{array}{c}0.272 * * \\
(0.119)\end{array}$ & $\begin{array}{c}0.308^{* *} \\
(0.120)\end{array}$ & $\begin{array}{c}0.272 * * \\
(0.120)\end{array}$ & $\begin{array}{c}0.273 * * \\
(0.120)\end{array}$ & $\begin{array}{c}0.255^{* *} \\
(0.119)\end{array}$ & $\begin{array}{c}0.259 * * \\
(0.120)\end{array}$ \\
\hline Growth options & $\begin{array}{c}-0.00666 \\
(0.00818)\end{array}$ & $\begin{array}{c}-0.00722 \\
(0.00755)\end{array}$ & $\begin{array}{c}-0.00624 \\
(0.00769)\end{array}$ & $\begin{array}{c}-0.00804 \\
(0.00803)\end{array}$ & $\begin{array}{r}-0.00809 \\
(0.00806)\end{array}$ & $\begin{array}{c}-0.00891 \\
(0.00781)\end{array}$ & $\begin{array}{c}-0.00909 \\
(0.00785)\end{array}$ \\
\hline Observations & 51,524 & 51,524 & 51,524 & 51,524 & 51,524 & 51,524 & 51,524 \\
\hline R-squared & 0.026 & 0.026 & 0.026 & 0.026 & 0.026 & 0.026 & 0.026 \\
\hline Number of parents & 3,871 & 3,871 & 3,871 & 3,871 & 3,871 & 3,871 & 3,871 \\
\hline
\end{tabular}




\section{Table 7. Internal leverage restrictions and the total debt and total borrowing by US affiliates}

The dependent variable is Total leverage which is the ratio of total US foreign affiliate debt to affiliate assets. Country tax rate is the median tax rate in the affiliate host country estimated annually using affiliate-level tax burdens. Internal leverage restriction is a dummy variable that equals 1 if a country imposes a quantitative restriction on the ratio of internal debt to the sum of internal debt and internal equity. Internal leverage ratio is the maximum ratio of internal debt to sum of internal debt and internal equity. Net PPE/assets is the ratio of net property, plant and equipment to assets in the affiliate. EBITDA/assets is the ratio of earnings before interest, depreciation and amortization to assets. Log of sales is the logarithm of sales. Creditor rights is an index of creditor rights from Djankov, McLiesh and Shleifer (2007). Political risk is the annual index of political risk from the International Country Risk Guide. Rate of inflation is the annual percentage in the consumer price index from the World Development Indicators. Growth options is the compound annual growth rate of total affiliate sales at the industry and country level. Regressions include parent, industry and year fixed effects, and standard errors correct for clustering across observations in country/industry cells. ${ }^{*}, *$, and $* * *$ denote significance at the $10 \%, 5 \%$, and $1 \%$ levels, respectively.

\begin{tabular}{|c|c|c|c|c|}
\hline \multirow{3}{*}{$\begin{array}{l}\text { VARIABLES } \\
\text { Country tax rate }\end{array}$} & (1) & (2) & (3) & (4) \\
\hline & $0.211^{* * *}$ & $0.224 * * *$ & $0.194 * * *$ & 0.178 \\
\hline & $(0.0345)$ & $(0.0360)$ & $(0.0341)$ & $(0.322)$ \\
\hline \multirow[t]{2}{*}{ Internal leverage restriction } & $-0.0082 * * *$ & 0.0331 & & \\
\hline & $(0.0009)$ & $(0.0330)$ & & \\
\hline Country tax rate $\times$ Internal leverage restriction & & -0.119 & & \\
\hline Internal leverage ratio & & & $\begin{array}{c}0.00463 * * \\
(0.0026)\end{array}$ & $\begin{array}{c}-0.0104 \\
(0.0988)\end{array}$ \\
\hline Country tax rate $\times$ Internal leverage ratio & & & & $\begin{array}{l}0.0175 \\
(0.331)\end{array}$ \\
\hline Net PPE/assets & $\begin{array}{c}0.0328 * * \\
(0.0138)\end{array}$ & $\begin{array}{c}0.0324 * * \\
(0.0138)\end{array}$ & $\begin{array}{c}0.0329 * * \\
(0.0137)\end{array}$ & $\begin{array}{c}0.0329 * * \\
(0.0138)\end{array}$ \\
\hline EBITDA/assets & $\begin{array}{c}-0.469 * * * \\
(0.0221)\end{array}$ & $\begin{array}{c}-0.469 * * * \\
(0.0221)\end{array}$ & $\begin{array}{c}-0.469 * * * \\
(0.0221)\end{array}$ & $\begin{array}{c}-0.469 * * * \\
(0.0221)\end{array}$ \\
\hline Log of sales & $\begin{array}{c}0.622 * * * \\
(0.220)\end{array}$ & $\begin{array}{c}0.624 * * * \\
(0.219)\end{array}$ & $\begin{array}{c}0.615^{* * *} \\
(0.220)\end{array}$ & $\begin{array}{c}0.615^{* * *} \\
(0.220)\end{array}$ \\
\hline Creditor rights & $\begin{array}{c}0.00762 * * * \\
(0.00290)\end{array}$ & $\begin{array}{c}0.00726 * * * \\
(0.00279)\end{array}$ & $\begin{array}{c}0.00863 * * * \\
(0.00275)\end{array}$ & $\begin{array}{c}0.00859 * * * \\
(0.00254)\end{array}$ \\
\hline Political risk & $\begin{array}{c}-0.194 * * * \\
(0.0344)\end{array}$ & $\begin{array}{c}-0.194 * * * \\
(0.0343)\end{array}$ & $\begin{array}{c}-0.201 * * * \\
(0.0350)\end{array}$ & $\begin{array}{c}-0.201 * * * \\
(0.0349)\end{array}$ \\
\hline Rate of inflation & $\begin{array}{c}-0.406 * * * \\
(0.0995)\end{array}$ & $\begin{array}{c}-0.424 * * * \\
(0.100)\end{array}$ & $\begin{array}{c}-0.370 * * * \\
(0.0955)\end{array}$ & $\begin{array}{c}-0.372 * * * \\
(0.0969)\end{array}$ \\
\hline Growth options & $\begin{array}{l}0.00188 \\
(0.0143)\end{array}$ & $\begin{array}{l}0.00285 \\
(0.0141)\end{array}$ & $\begin{array}{l}0.00359 \\
(0.0149)\end{array}$ & $\begin{array}{l}0.00364 \\
(0.0149)\end{array}$ \\
\hline Observations & 54,269 & 54,269 & 54,269 & 54,269 \\
\hline R-squared & 0.097 & 0.097 & 0.097 & 0.097 \\
\hline Number of parents & 3,943 & 3,943 & 3,943 & 3,943 \\
\hline
\end{tabular}




\section{Table 8. The application of thin capitalization rules and US affiliate financing}

The dependent variable in columns (1) to (3) is Total leverage, which is the total debt to assets ratio of the US foreign affiliate, the dependent variable in columns (4) and (5) is Internal leverage, which is the ratio of internal debt to total equity of the US foreign affiliate, and the dependent variable in columns (6) and (7) is Internal debt share, which is the ratio of internal debt owed to its parent to total debt of the US foreign affiliate. Country tax rate is the median tax rate in the affiliate host country estimated annually using affiliate-level tax burdens. Thin cap restriction is a dummy variable that equals 1 if a country has a thin capitalization rule and zero otherwise. Total leverage restriction is a dummy variable that equals 1 if a country imposes a quantitative restriction on the ratio of total debt to assets and zero otherwise. Internal leverage restriction is a dummy variable that equals 1 if a country imposes a quantitative restriction on the ratio of internal debt to the sum of internal debt and internal equity. Arm's length is a dummy variable if a country applies a remedy following arm's length considerations. Net PPE/assets is the ratio of net property, plant and equipment to assets in the affiliate. EBITDA/assets is the ratio of earnings before interest, depreciation and amortization to assets. Log of sales is the logarithm of sales. Creditor rights is an index of creditor rights from Djankov, McLiesh and Shleifer (2007). Political risk is the annual index of political risk from the International Country Risk Guide. Rate of inflation is the annual percentage in the consumer price index from the World Development Indicators. Growth options is the compound annual growth rate of total affiliate sales at the industry and country level. Regressions include parent, industry and year fixed effects, and standard errors correct for clustering across observations in country/industry cells. *,**, and $* * *$ denote significance at the $10 \%, 5 \%$, and $1 \%$ levels, respectively.

\begin{tabular}{|c|c|c|c|c|c|c|c|}
\hline VARIABLES & $\begin{array}{c}(1) \\
\text { Total } \\
\text { leverage }\end{array}$ & $\begin{array}{c}(2) \\
\text { Total } \\
\text { leverage }\end{array}$ & $\begin{array}{c}3) \\
\text { Total } \\
\text { leverage }\end{array}$ & $\begin{array}{c}4) \\
\text { Internal } \\
\text { leverage }\end{array}$ & $\begin{array}{c}5) \\
\text { Internal } \\
\text { leverage }\end{array}$ & $\begin{array}{c}(6) \\
\text { Internal } \\
\text { debt share }\end{array}$ & $\begin{array}{c}(7) \\
\text { Internal } \\
\text { debt share }\end{array}$ \\
\hline Country tax rate & $\begin{array}{c}0.224 * * * \\
(0.0320)\end{array}$ & $\begin{array}{l}0.183 * * * \\
(0.0319)\end{array}$ & $\begin{array}{l}0.217 * * * \\
(0.0348)\end{array}$ & $\begin{array}{c}0.463 * * * \\
(0.0948)\end{array}$ & $\begin{array}{l}0.481^{* * *} \\
(0.104)\end{array}$ & $\begin{array}{l}0.128 * * * \\
(0.0336)\end{array}$ & $\begin{array}{l}0.129^{* * *} \\
(0.0336)\end{array}$ \\
\hline Thin cap restriction & $\begin{array}{l}-0.0276 * * * \\
(0.00856)\end{array}$ & & & $\begin{array}{c}-0.0781 * * * \\
(0.0202)\end{array}$ & & $\begin{array}{l}-0.00903 \\
(0.00717)\end{array}$ & \\
\hline Total leverage restriction & & $\begin{array}{l}-0.0229 * * * \\
(0.00786)\end{array}$ & & & & & \\
\hline Internal leverage restriction & & & $\begin{array}{l}-0.0200^{* *} \\
(0.0103)\end{array}$ & & $\begin{array}{l}-0.0575^{* *} \\
(0.0282)\end{array}$ & & $\begin{array}{l}-0.00312 \\
(0.0106)\end{array}$ \\
\hline $\begin{array}{l}\text { Thin cap restriction } \times \\
\text { Arm's length }\end{array}$ & $\begin{array}{l}0.0169 * * \\
(0.00847)\end{array}$ & & & $\begin{array}{l}-0.00298 \\
(0.0277)\end{array}$ & & $\begin{array}{l}-0.00369 \\
(0.00801)\end{array}$ & \\
\hline $\begin{array}{l}\text { Total leverage restriction } \times \\
\text { Arm's length }\end{array}$ & & $\begin{array}{c}0.0109 \\
(0.00964)\end{array}$ & & & & & \\
\hline $\begin{array}{l}\text { Internal leverage restriction } \times \\
\text { Arm's length }\end{array}$ & & & $\begin{array}{l}0.0244^{*} \\
(0.0145)\end{array}$ & & $\begin{array}{l}-0.0167 \\
(0.0343)\end{array}$ & & $\begin{array}{l}-0.0121 \\
(0.0112)\end{array}$ \\
\hline Net PPE/assets & $\begin{array}{c}0.0354 * * \\
(0.0139)\end{array}$ & $\begin{array}{c}0.0357 * * \\
(0.0138)\end{array}$ & $\begin{array}{c}0.0353 * * \\
(0.0139)\end{array}$ & $\begin{array}{l}-0.0751 \\
(0.0504)\end{array}$ & $\begin{array}{l}-0.0768 \\
(0.0502)\end{array}$ & $\begin{array}{c}0.108 * * * \\
(0.0130)\end{array}$ & $\begin{array}{l}0.107 * * * \\
(0.0130)\end{array}$ \\
\hline EBITDA/assets & $\begin{array}{l}-0.487 * * * \\
(0.0215)\end{array}$ & $\begin{array}{l}-0.487 * * * \\
(0.0215)\end{array}$ & $\begin{array}{c}-0.487 * * * \\
(0.0215)\end{array}$ & $\begin{array}{l}0.112 * * * \\
(0.0373)\end{array}$ & $\begin{array}{l}0.114 * * * \\
(0.0372)\end{array}$ & $\begin{array}{l}-0.129 * * * \\
(0.00924)\end{array}$ & $\begin{array}{r}-0.129 * * * \\
(0.00926)\end{array}$ \\
\hline Log of sales & $\begin{array}{c}0.488^{* *} \\
(0.207)\end{array}$ & $\begin{array}{l}0.469 * * \\
(0.208)\end{array}$ & $\begin{array}{c}0.474^{* *} \\
(0.208)\end{array}$ & $\begin{array}{l}1.958 * * * \\
(0.497)\end{array}$ & $\begin{array}{l}1.923 * * * \\
(0.495)\end{array}$ & $\begin{array}{c}-0.287 * * \\
(0.118)\end{array}$ & $\begin{array}{c}-0.294 * * \\
(0.115)\end{array}$ \\
\hline Creditor rights & $\begin{array}{l}0.00727 * * \\
(0.00331)\end{array}$ & $\begin{array}{c}0.0105 * * * \\
(0.00326)\end{array}$ & $\begin{array}{l}0.00584 * \\
(0.00297)\end{array}$ & $\begin{array}{c}0.00911 \\
(0.00817)\end{array}$ & $\begin{array}{c}0.00192 \\
(0.00896)\end{array}$ & $\begin{array}{c}0.00384 \\
(0.00269)\end{array}$ & $\begin{array}{c}0.00332 \\
(0.00296)\end{array}$ \\
\hline Political risk & $\begin{array}{c}-0.164 * * * \\
(0.0315)\end{array}$ & $\begin{array}{c}-0.183 * * * \\
(0.0340)\end{array}$ & $\begin{array}{c}-0.178^{* * *} \\
(0.0336)\end{array}$ & $\begin{array}{c}-0.0665 \\
(0.111)\end{array}$ & $\begin{array}{l}-0.129 \\
(0.117)\end{array}$ & $\begin{array}{c}-0.144^{* * *} \\
(0.0302)\end{array}$ & $\begin{array}{c}-0.155^{* * * *} \\
(0.0328)\end{array}$ \\
\hline Rate of inflation & $\begin{array}{c}-0.432 * * * \\
(0.0982)\end{array}$ & $\begin{array}{c}-0.339 * * * \\
(0.0957)\end{array}$ & $\begin{array}{c}-0.403 * * * \\
(0.0994)\end{array}$ & $\begin{array}{c}-2.421 * * * \\
(0.751)\end{array}$ & $\begin{array}{c}-2.427 * * * \\
(0.754)\end{array}$ & $\begin{array}{c}0.307 * * * \\
(0.119)\end{array}$ & $\begin{array}{c}0.312^{* * *} * \\
(0.120)\end{array}$ \\
\hline Growth options & $\begin{array}{c}0.00552 \\
(0.0112)\end{array}$ & $\begin{array}{l}0.00696 \\
(0.0130)\end{array}$ & $\begin{array}{l}0.00216 \\
(0.0135)\end{array}$ & $\begin{array}{l}-0.0330 \\
(0.0305)\end{array}$ & $\begin{array}{c}-0.0394 \\
(0.0350)\end{array}$ & $\begin{array}{c}-0.00702 \\
(0.00725)\end{array}$ & $\begin{array}{c}-0.00743 \\
(0.00769)\end{array}$ \\
\hline Observations & 54,262 & 54,262 & 54,262 & 52,092 & 52,092 & 51,524 & 51,524 \\
\hline R-squared & 0.099 & 0.098 & 0.098 & 0.003 & 0.003 & 0.027 & 0.027 \\
\hline Number of parents & 3,941 & 3,941 & 3,941 & 3,868 & 3,868 & 3,871 & 3,871 \\
\hline
\end{tabular}




\section{Table 9. The short-term impact of changes in thin capitalization rules on US affiliate financing}

All variables are in one-period changes between benchmark years. The dependent variable in the regressions reported in columns (1) to (3) is the one-period change in total debt to assets ratio of the US foreign affiliate. The dependent variable in the regressions reported in columns (4) and (5) is the one-period change in the ratio of internal debt to total equity of the US foreign affiliate. The dependent variable in the regressions reported in columns (6) and (7) is the one-period change in the ratio of internal debt owed to its parent to total debt of the US foreign affiliate. Country tax rate is the median tax rate in the affiliate host country estimated annually using affiliate-level tax burdens. Thin cap restriction is a dummy variable that equals 1 if a country has a thin capitalization rule and zero otherwise. Total leverage restriction is a dummy variable that equals 1 if a country imposes a quantitative restriction on the ratio of total debt to assets and zero otherwise. Internal leverage restriction is a dummy variable that equals 1 if a country imposes a quantitative restriction on the ratio of internal debt to the sum of internal debt and internal equity. Net PPE/assets is the ratio of net property, plant and equipment to assets in the affiliate. EBITDA/assets is the ratio of earnings before interest, depreciation and amortization to assets. Log of sales is the logarithm of sales. Creditor rights is an index of creditor rights from Djankov, McLiesh and Shleifer (2007). Political risk is the annual index of political risk from the International Country Risk Guide. Rate of inflation is the annual percentage in the consumer price index from the World Development Indicators. Growth options is the compound annual growth rate of total affiliate sales at the industry and country level. Regressions include parent, industry and year fixed effects, and standard errors correct for clustering across observations in country/industry cells. $* * *$, and $* * *$ denote significance at the $10 \%, 5 \%$, and $1 \%$ levels, respectively.

\begin{tabular}{|c|c|c|c|c|c|c|c|}
\hline VARIABLES & $\begin{array}{c}(1) \\
\text { Change in } \\
\text { total } \\
\text { leverage }\end{array}$ & $\begin{array}{c}(2) \\
\text { Change in } \\
\text { total } \\
\text { leverage }\end{array}$ & $\begin{array}{c}(3) \\
\text { Change in } \\
\text { total } \\
\text { leverage }\end{array}$ & $\begin{array}{c}(4) \\
\text { Change in } \\
\text { internal } \\
\text { leverage }\end{array}$ & $\begin{array}{c}(5) \\
\text { Change in } \\
\text { internal } \\
\text { leverage }\end{array}$ & $\begin{array}{c}(6) \\
\text { Change in } \\
\text { internal debt } \\
\text { share }\end{array}$ & $\begin{array}{c}(7) \\
\text { Change in } \\
\text { internal } \\
\text { debt share }\end{array}$ \\
\hline$\Delta$ Country tax rate & $\begin{array}{c}0.167 * * \\
(0.0672)\end{array}$ & $\begin{array}{c}0.175^{* *} \\
(0.0674)\end{array}$ & $\begin{array}{c}0.171^{* *} \\
(0.0675)\end{array}$ & $\begin{array}{l}0.0262 \\
(0.397)\end{array}$ & $\begin{array}{c}-0.247 \\
(0.382)\end{array}$ & $\begin{array}{c}-0.000937 \\
(0.0646)\end{array}$ & $\begin{array}{c}0.0209 \\
(0.0623)\end{array}$ \\
\hline$\Delta$ Thin cap restriction & $\begin{array}{l}-0.0113^{*} \\
(0.00630)\end{array}$ & & & $\begin{array}{c}-0.0452 * * \\
(0.0231)\end{array}$ & & $\begin{array}{c}-0.00162 \\
(0.00942)\end{array}$ & \\
\hline$\Delta$ Total leverage restriction & & $\begin{array}{c}-0.0248 * * \\
(0.0108)\end{array}$ & & & & & \\
\hline$\Delta$ Internal leverage restriction & & & $\begin{array}{c}0.0048 \\
(0.0082)\end{array}$ & & $\begin{array}{c}-0.117 * * \\
(0.0573)\end{array}$ & & $\begin{array}{c}-0.00395 \\
(0.0106)\end{array}$ \\
\hline$\Delta$ Net PPE/assets & $\begin{array}{c}0.160 * * * \\
(0.0333)\end{array}$ & $\begin{array}{c}0.159 * * * \\
(0.0333)\end{array}$ & $\begin{array}{c}0.159 * * * \\
(0.0334)\end{array}$ & $\begin{array}{l}0.0569 \\
(0.165)\end{array}$ & $\begin{array}{c}0.0479 \\
(0.165)\end{array}$ & $\begin{array}{c}0.184 * * * \\
(0.0346)\end{array}$ & $\begin{array}{c}0.184 * * * \\
(0.0344)\end{array}$ \\
\hline$\Delta$ EBITDA/assets & $\begin{array}{c}-0.339 * * * \\
(0.0237)\end{array}$ & $\begin{array}{c}-0.339 * * * \\
(0.0238)\end{array}$ & $\begin{array}{c}-0.339 * * * \\
(0.0237)\end{array}$ & $\begin{array}{c}-0.0907 \\
(0.0969)\end{array}$ & $\begin{array}{c}-0.0773 \\
(0.0974)\end{array}$ & $\begin{array}{c}-0.123 * * * \\
(0.0161)\end{array}$ & $\begin{array}{c}-0.126 * * * \\
(0.0159)\end{array}$ \\
\hline$\Delta$ Log of sales & $\begin{array}{c}1.165 * * * \\
(0.296)\end{array}$ & $\begin{array}{c}1.169^{* * *} \\
(0.296)\end{array}$ & $\begin{array}{c}1.158 * * * \\
(0.296)\end{array}$ & $\begin{array}{l}2.442 * \\
(1.374)\end{array}$ & $\begin{array}{l}2.472 * \\
(1.400)\end{array}$ & $\begin{array}{c}0.731 * * * \\
(0.237)\end{array}$ & $\begin{array}{c}0.710^{* * *} \\
(0.235)\end{array}$ \\
\hline$\Delta$ Creditor rights & $\begin{array}{c}0.0133 \\
(0.0141)\end{array}$ & $\begin{array}{c}0.0135 \\
(0.0142)\end{array}$ & $\begin{array}{c}0.0110 \\
(0.0142)\end{array}$ & $\begin{array}{c}-0.0292 \\
(0.0760)\end{array}$ & $\begin{array}{c}-0.0251 \\
(0.0744)\end{array}$ & $\begin{array}{c}0.0093 \\
(0.0133)\end{array}$ & $\begin{array}{c}0.0014 \\
(0.0133)\end{array}$ \\
\hline$\Delta$ Political risk & $\begin{array}{c}-0.0638 \\
(0.0670)\end{array}$ & $\begin{array}{c}-0.0612 \\
(0.0660)\end{array}$ & $\begin{array}{c}-0.0542 \\
(0.0665)\end{array}$ & $\begin{array}{c}0.525 \\
(0.435)\end{array}$ & $\begin{array}{c}0.417 \\
(0.421)\end{array}$ & $\begin{array}{c}0.0603 \\
(0.0891)\end{array}$ & $\begin{array}{c}0.0445 \\
(0.0869)\end{array}$ \\
\hline$\Delta$ Rate of inflation & $\begin{array}{c}-0.388 * * * \\
(0.105)\end{array}$ & $\begin{array}{c}-0.391^{* * *} \\
(0.105)\end{array}$ & $\begin{array}{c}-0.398^{* * *} \\
(0.105)\end{array}$ & $\begin{array}{c}-0.269 \\
(1.193)\end{array}$ & $\begin{array}{c}-0.119 \\
(1.177)\end{array}$ & $\begin{array}{c}0.182 \\
(0.151)\end{array}$ & $\begin{array}{c}0.045 \\
(0.145)\end{array}$ \\
\hline$\Delta$ Growth options & $\begin{array}{c}0.0119 \\
(0.0116)\end{array}$ & $\begin{array}{c}0.0164 \\
(0.0121)\end{array}$ & $\begin{array}{c}0.0104 \\
(0.0128)\end{array}$ & $\begin{array}{c}-0.000860 \\
(0.0968)\end{array}$ & $\begin{array}{c}-0.00108 \\
(0.0927)\end{array}$ & $\begin{array}{c}-0.0135 \\
(0.0132)\end{array}$ & $\begin{array}{c}-0.0138 \\
(0.0136)\end{array}$ \\
\hline Observations & 15,202 & 15,202 & 15,202 & 14,518 & 14,518 & 14,366 & 14,366 \\
\hline R-squared & 0.061 & 0.061 & 0.061 & 0.002 & 0.002 & 0.015 & 0.014 \\
\hline Number of parents & 1,634 & 1,634 & 1,634 & 1,607 & 1,607 & 1,606 & 1,606 \\
\hline
\end{tabular}




\section{Table 10. Impact of thin capitalization rules on Tobin's $Q$, debt, and interest expense at the consolidated firm level}

The dependent variable in columns 1 and 2 is Tobin's $q$, defined as the ratio of the market value of the overall firm's equity plus debt to total assets. The dependent variable in columns 3 and 4 is Industry-adjusted Tobin's $q$, defined as Tobin's q minus the firm's industry mean Tobin's q. The dependent variable in columns 5 and 6 , Aggregate debt, is the ratio of total debt to total assets of the consolidated multinational firm estimated using Compustat data. The dependent variable in columns 7 and 8, Aggregate interest expense, is the ratio of interest expenses to total assets of the consolidated multinational firm. The dependent variable in columns 9 and 10 , Aggregate interest expense to debt, is the ratio of interest expenses to total debt of the consolidated firm. Aggregate thin cap restriction is the ratio of the sum of the assets of foreign affiliates subject to a thin cap restriction to the total assets of the consolidated firm. Aggregate total leverage restriction is the ratio of the sum of the assets of foreign affiliates subject to a total leverage restriction to the total assets of the consolidated firm. Aggregate internal leverage restriction is the ratio of the sum of the assets of foreign affiliates subject to an internal leverage restriction to the total assets of the consolidated firm. Net PPE/assets is the ratio of net property, plant and equipment to assets of the consolidated firm. EBITDA/assets is the ratio of earnings before interest, depreciation and amortization to assets. Log of sales is the logarithm of sales. Creditor rights is an index of creditor rights from Djankov, McLiesh and Shleifer (2007). Political risk is the annual index of political risk from the International Country Risk Guide. Rate of inflation is the annual percentage in the consumer price index from the World Development Indicators. Growth options is the compound annual growth rate of sales at the industry and country level. Regressions include year and industry fixed effects, except regressions 3 and 4 which include year fixed effects. Standard errors correct for clustering at the parent level. *, **, and ${ }^{* * *}$ denote significance at the $10 \%, 5 \%$, and $1 \%$ levels, respectively.

\begin{tabular}{|c|c|c|c|c|c|c|c|c|c|c|}
\hline VARIABLES & $\begin{array}{c}\text { (1) } \\
\text { Tobin's q }\end{array}$ & $\begin{array}{c}(2) \\
\text { Tobin's q }\end{array}$ & $\begin{array}{c}(3) \\
\text { Industry- } \\
\text { adjusted } \\
\text { Tobin's q }\end{array}$ & $\begin{array}{c}\text { (4) } \\
\text { Industry- } \\
\text { adjusted } \\
\text { Tobin's q }\end{array}$ & $\begin{array}{c}(5) \\
\text { Aggregate } \\
\text { debt }\end{array}$ & $\begin{array}{c}(6) \\
\text { Aggregate } \\
\text { debt }\end{array}$ & $\begin{array}{c}(7) \\
\text { Aggregate } \\
\text { interest } \\
\text { expense }\end{array}$ & $\begin{array}{c}(8) \\
\text { Aggregate } \\
\text { interest } \\
\text { expense }\end{array}$ & $\begin{array}{c}(9) \\
\text { Aggregate } \\
\text { interest expense } \\
\text { to debt }\end{array}$ & $\begin{array}{c}(10) \\
\text { Aggregate } \\
\text { interest expense } \\
\text { to debt }\end{array}$ \\
\hline $\begin{array}{l}\text { Aggregate thin cap } \\
\text { restriction }\end{array}$ & $\begin{array}{l}-0.182 \\
(0.165)\end{array}$ & & $\begin{array}{l}-0.178 \\
(0.157)\end{array}$ & & $\begin{array}{c}-0.00338 \\
(0.0111)\end{array}$ & & $\begin{array}{c}-0.00514 * * * \\
(0.00134)\end{array}$ & & $\begin{array}{c}-0.136 * * * \\
(0.00879)\end{array}$ & \\
\hline $\begin{array}{l}\text { Aggregate total } \\
\text { leverage restriction } \\
\text { Aggregate internal } \\
\text { leverage restriction }\end{array}$ & & $\begin{array}{c}-0.523 * * * \\
(0.180) \\
0.00893 \\
(0.248)\end{array}$ & & $\begin{array}{c}-0.453 * * \\
(0.202) \\
-0.0531 \\
(0.233)\end{array}$ & & $\begin{array}{c}0.0199 \\
(0.0175) \\
-0.0139 \\
(0.0174)\end{array}$ & & $\begin{array}{c}-0.00286 * * * \\
(0.00106) \\
-0.00645 * * * \\
(0.00179)\end{array}$ & & $\begin{array}{c}-0.126 * * * \\
(0.0132) \\
-0.159 * * * \\
(0.0111)\end{array}$ \\
\hline Net PPE/Assets & $\begin{array}{c}-0.773 * * * \\
(0.108)\end{array}$ & $\begin{array}{c}-0.778 * * * \\
(0.108)\end{array}$ & $\begin{array}{l}-0.0864 \\
(0.0899)\end{array}$ & $\begin{array}{l}-0.0893 \\
(0.0903)\end{array}$ & $\begin{array}{c}0.224 * * * \\
(0.0247)\end{array}$ & $\begin{array}{l}0.224 * * * \\
(0.0246)\end{array}$ & $\begin{array}{l}0.0115 * * * \\
(0.00175)\end{array}$ & $\begin{array}{l}0.0115^{* * *} \\
(0.00175)\end{array}$ & $\begin{array}{c}0.0917 * * * \\
(0.0148)\end{array}$ & $\begin{array}{c}0.0912 * * * \\
(0.0148)\end{array}$ \\
\hline EBITDA/Assets & $\begin{array}{c}5.621 * * * \\
(0.380)\end{array}$ & $\begin{array}{l}5.610 * * * \\
(0.379)\end{array}$ & $\begin{array}{c}4.737 * * * \\
(0.357)\end{array}$ & $\begin{array}{c}4.732 * * * \\
(0.356)\end{array}$ & $\begin{array}{c}-0.416 * * * \\
(0.0467)\end{array}$ & $\begin{array}{c}-0.415 * * * \\
(0.0468)\end{array}$ & $\begin{array}{c}-0.0172 * * * \\
(0.00228)\end{array}$ & $\begin{array}{c}-0.0172 * * * \\
(0.00228)\end{array}$ & $\begin{array}{c}-0.0529 * * * \\
(0.0175)\end{array}$ & $\begin{array}{c}-0.0526 * * * \\
(0.0175)\end{array}$ \\
\hline Log of sales & $\begin{array}{c}-0.065 * * * \\
(0.0109)\end{array}$ & $\begin{array}{c}-0.0653 * * * \\
(0.0110)\end{array}$ & $\begin{array}{c}-0.0227^{*} \\
(0.0118)\end{array}$ & $\begin{array}{l}-0.0225^{*} \\
(0.0118)\end{array}$ & $\begin{array}{l}0.00527 * * \\
(0.00235)\end{array}$ & $\begin{array}{l}0.00524 * * \\
(0.00234)\end{array}$ & $\begin{array}{c}0.000427 * * * \\
(0.000143)\end{array}$ & $\begin{array}{c}0.000433 * * * \\
(0.000143)\end{array}$ & $\begin{array}{c}-0.00211^{*} \\
(0.00113)\end{array}$ & $\begin{array}{c}-0.00200^{*} \\
(0.00113)\end{array}$ \\
\hline Creditor rights & $\begin{array}{c}0.0416^{* *} \\
(0.0212)\end{array}$ & $\begin{array}{c}0.0596 * * * \\
(0.0214)\end{array}$ & $\begin{array}{c}-0.0430 * * \\
(0.0216)\end{array}$ & $\begin{array}{l}-0.0293 \\
(0.0221)\end{array}$ & $\begin{array}{l}-0.00566 \\
(0.00415)\end{array}$ & $\begin{array}{l}-0.00730 * \\
(0.00436)\end{array}$ & $\begin{array}{c}1.24 \mathrm{e}-05 \\
(0.000255)\end{array}$ & $\begin{array}{l}-0.000117 \\
(0.000274)\end{array}$ & $\begin{array}{c}-0.00694 * * * \\
(0.00233)\end{array}$ & $\begin{array}{c}-0.00803 * * * \\
(0.00260)\end{array}$ \\
\hline Political risk & $\begin{array}{c}0.401 \\
(0.251)\end{array}$ & $\begin{array}{c}0.381 \\
(0.259)\end{array}$ & $\begin{array}{l}0.238 \\
(0.291)\end{array}$ & $\begin{array}{c}0.227 \\
(0.299)\end{array}$ & $\begin{array}{c}0.0244 \\
(0.0567)\end{array}$ & $\begin{array}{c}0.0243 \\
(0.0566)\end{array}$ & $\begin{array}{l}-0.000697 \\
(0.00402)\end{array}$ & $\begin{array}{l}-0.000673 \\
(0.00403)\end{array}$ & $\begin{array}{l}-0.0179 \\
(0.0400)\end{array}$ & $\begin{array}{l}-0.0150 \\
(0.0400)\end{array}$ \\
\hline Rate of inflation & $\begin{array}{l}0.00567 \\
(0.0158)\end{array}$ & $\begin{array}{l}0.00928 \\
(0.0156)\end{array}$ & $\begin{array}{l}-0.0132 \\
(0.0196)\end{array}$ & $\begin{array}{l}-0.0105 \\
(0.0192)\end{array}$ & $\begin{array}{l}-0.00427 \\
(0.00545)\end{array}$ & $\begin{array}{l}-0.00465 \\
(0.00544)\end{array}$ & $\begin{array}{c}0.000148 \\
(0.000605)\end{array}$ & $\begin{array}{c}0.000132 \\
(0.000605)\end{array}$ & $\begin{array}{c}0.00138 \\
(0.00405)\end{array}$ & $\begin{array}{c}0.00126 \\
(0.00406)\end{array}$ \\
\hline Growth options & $\begin{array}{l}0.0200 \\
(0.107)\end{array}$ & $\begin{array}{l}0.0639 \\
(0.105)\end{array}$ & $\begin{array}{l}0.0479 \\
(0.111)\end{array}$ & $\begin{array}{l}0.0820 \\
(0.111)\end{array}$ & $\begin{array}{c}-0.00295 \\
(0.0217)\end{array}$ & $\begin{array}{c}-0.00985 \\
(0.0221)\end{array}$ & $\begin{array}{l}-0.00123 \\
(0.00141)\end{array}$ & $\begin{array}{l}-0.00147 \\
(0.00141)\end{array}$ & $\begin{array}{c}-0.0199 * \\
(0.0106)\end{array}$ & $\begin{array}{c}-0.0218^{* *} \\
(0.0105)\end{array}$ \\
\hline $\begin{array}{l}\text { Observations } \\
\text { R-squared }\end{array}$ & $\begin{array}{l}4,558 \\
0.279\end{array}$ & $\begin{array}{l}4,558 \\
0.279\end{array}$ & $\begin{array}{l}4,558 \\
0.130\end{array}$ & $\begin{array}{l}4,558 \\
0.131\end{array}$ & $\begin{array}{l}4,696 \\
0.110\end{array}$ & $\begin{array}{l}4,696 \\
0.111\end{array}$ & $\begin{array}{l}9,705 \\
0.116\end{array}$ & $\begin{array}{l}9,705 \\
0.116\end{array}$ & $\begin{array}{l}9,705 \\
0.135\end{array}$ & $\begin{array}{l}9,705 \\
0.136\end{array}$ \\
\hline
\end{tabular}




\section{Figure 1. US affiliates' debt ratios and corporate taxation}

This figure displays mean values across time over US affiliate total leverage (equal to the ratio of total US foreign affiliate debt to affiliate assets), internal leverage (equal to the ratio of internal debt owed to the parent to affiliate equity), internal debt share (equal to the ratio of internal debt owed to the parent to total affiliate debt, and country-level corporate tax rate (equal to the median tax rate in the affiliate host country estimated annually using affiliate-level tax burdens) per cohort (for the years 1982, 1989, 1994, 1999, 2004).

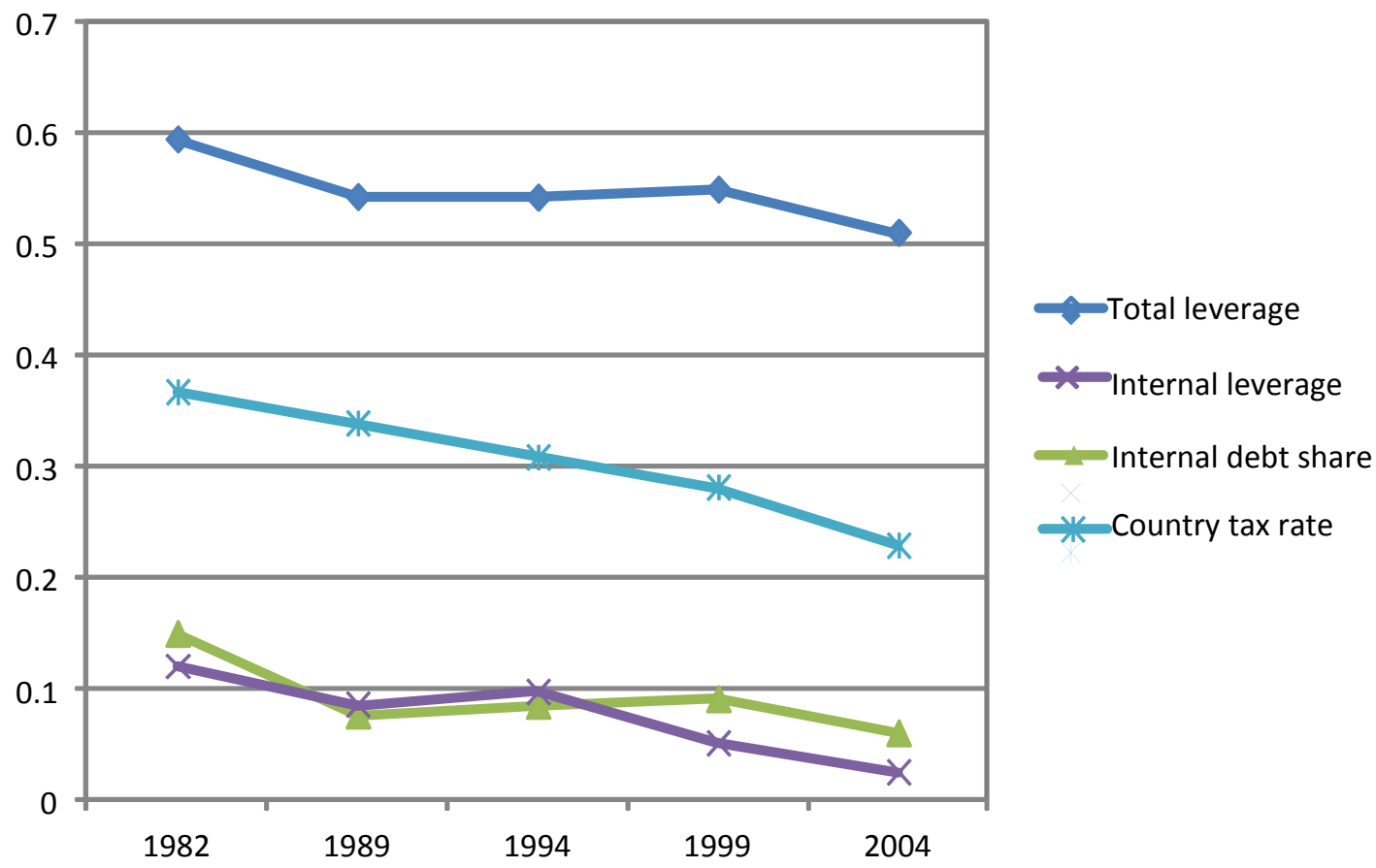

